SOCIEDADE BRASILEIRA DE GEOLOGIA

\title{
CONTRIBUIÇÕES À GEOLOGIA DO RIO GRANDE DO SUL E DE SANTA CATARINA
}

ANDRÉA RITTER JELINEK

CARLOS AUGUSTO SOMMER

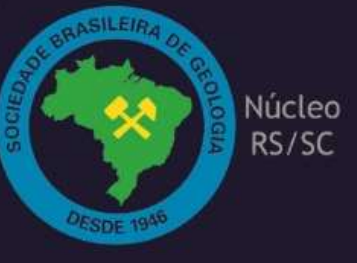

$\left.\int^{3}\right|^{2}$
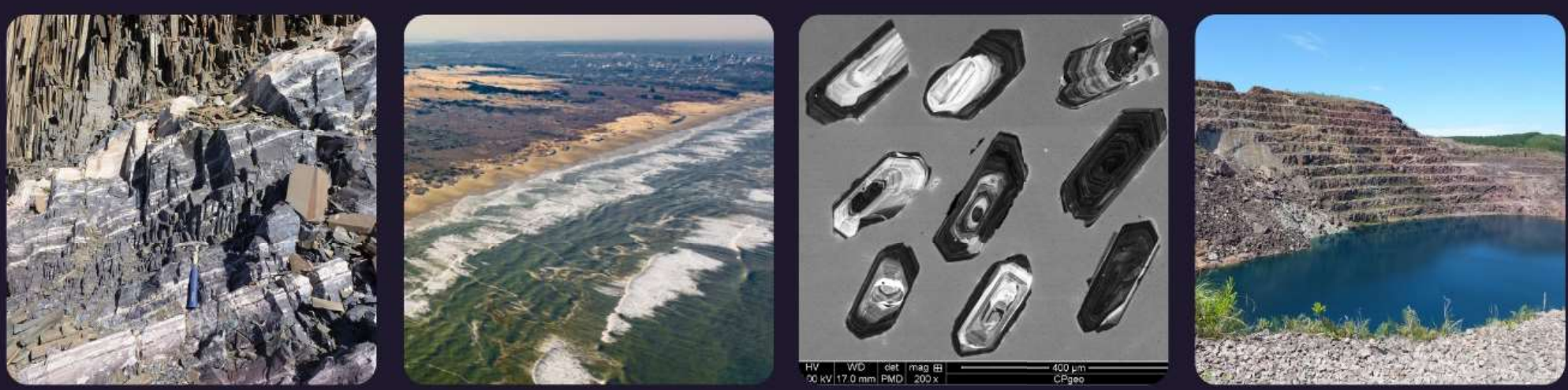


\section{IMAGENS DE CAPA E CONTRACAPA}
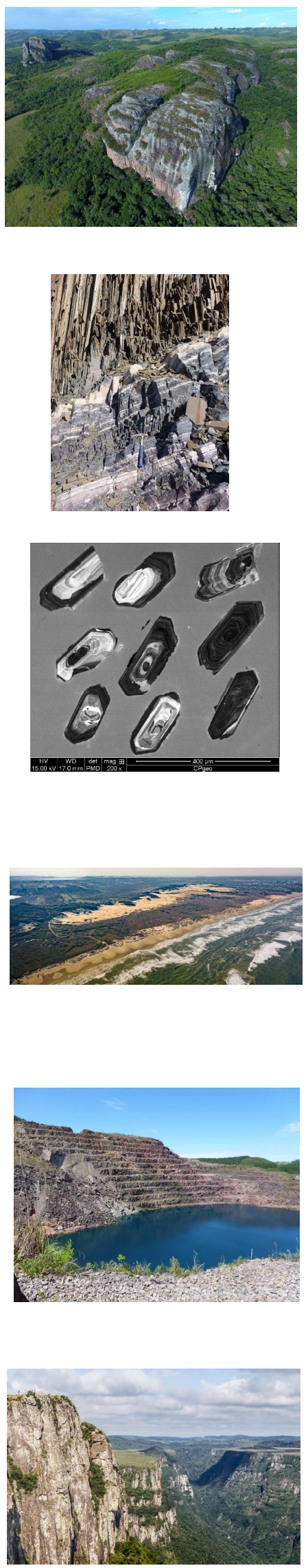

Fotografia aérea do setor norte da Serra do Segredo, em Caçapava do Sul, RS, onde se destacam a Pedra do Segredo, em primeiro plano, e a Pedra da Abelha, logo à esquerda, geoformas esculpidas sobre conglomerados fluviais da Bacia do Camaquã. Ao fundo, alguns cerros formados por rochas metamórficas e o imponente alto de Caçapava, sobre granitoides diversos, rochas que registram diferentes momentos do Ciclo Brasiliano no sul do Brasil. A paisagem faz parte do Geoparque Caçapava Aspirante Unesco e é parcialmente inserida no Parque Natural Municipal da Pedra do Segredo. Imagem obtida por Felipe Guadagnin. Legenda de André Weissheimer de Borba e Felipe Guadagnin.

Contato entre rochas sedimentares da Bacia do Paraná e soleira de diabásio do Grupo Serra Geral. Pedreira Carollo, região de Montenegro, RS. Imagem e legenda de Carlos Augusto Sommer.

Imagem de catodoluminescência de cristais de zircão pertencentes ao Batólito de Florianópolis. Aumento de 200 vezes. Imagem e legenda de Andréa Ritter Jelinek.

Fotografia aérea oblíqua apresentando a morfologia da região correspondente ao extremo do Litoral Norte do RS, à direita observa-se a cidade de Torres/RS. Em primeiro plano observa-se a morfologia do campo de dunas localizado no Parque Estadual de Itapeva. Unidade essa localizada sobre o sistema Laguna-Barreira IV (holocênico). Logo após o baixio, na retaguarda do campo de dunas, ocorre a morfologia do sistema Laguna-Barreira III (pleistocênico). Ao fundo, com o relevo mais elevado, encontra-se a Formação Serra Geral pertencente à Bacia do Paraná. Imagem obtida por Eduardo H. R. Russo. Legenda de Eduardo Guimarães Barboza.

Minas do Camaquã. Mineração de cobre a céu aberto. Caçapava do Sul. Imagem e legenda de Carlos Augusto Sommer.

Derrames ácidos do Grupo Serra Geral, Bacia do Paraná, na região do Cânion Fortaleza, Parque Nacional da Serra Geral, Cambará do Sul, RS. Imagem licenciada de Depositphotos. Legenda de Carlos Augusto Sommer. 
PUBLICAÇÃO ESPECIAL DO NÚCLEO RS/SC DA SOCIEDADE BRASILEIRA DE GEOLOGIA

\section{CONTRIBUIÇÕES À GEOLOGIA DO RIO GRANDE DO SUL E DE SANTA CATARINA}

Editores

Andréa Ritter Jelinek

Carlos Augusto Sommer

\section{CO PASSO}

Porto Alegre, RS, 2021. 
É proibida a reprodução total ou parcial desta obra, sem autorização expressa dos autores ou da editora. A violação importará nas providências judiciais previstas no artigo 102, da Lei no 9.610/1998, sem prejuízo da responsabilidade criminal. Os textos deste livro são de responsabilidade de seus autores.

ISBN E-book: 978-65-89013-03-7

Edição: $1^{\underline{a}}$

Ano: 2021

\section{Editora Compasso Lugar Cultura}

Responsável André Suertegaray Rossato

Porto Alegre - RS - Brasil

Telefones (51) 984269928

compassolugarcultura@gmail.com

www.compassolugarcultura.com

Editores:

Andréa Ritter Jelinek

Carlos Augusto Sommer

Diagramador: Gabriel Zambom

Revisão de Texto: Gustavo Saldivar

\author{
Conselho Editorial Compasso Lugar Cultura \\ Álvaro Heidrich \\ Carlos Henrique Aigner \\ Cláudia Luíza Zeferino Pires \\ Dakir Larara Machado da Silva \\ Dilermando Cattaneo da Silveira \\ Dirce Maria Antunes Suertegaray \\ Helena Copetti Callai \\ Jaeme Luiz Callai \\ João Osvaldo Rodrigues Nunes \\ Laurindo Antonio Guasselli \\ Maíra Suertegaray Rossato \\ Nelson Rego \\ Roberto Verdum \\ Rosa Maria Vieira Medeiros \\ Sinthia Batista
}

\section{Realização}

Sociedade Brasileira de Geologia

Diretoria Núcleo RS/SC:

Diretora Presidente: Andréa Ritter Jelinek

Diretor Vice-Presidente: Carlos Augusto Sommer

Diretor Secretário: Lucas Debatin Vieira

Diretor Financeiro: Breno Leitão Weichel

Diretora de Programação Técnico-Científica: Rosemary Hoff

Dados Internacionais de Catalogação na Publicação (CIP)

$\mathrm{J} 47 \mathrm{c}$

Jelinek, Andréa Ritter.

Contribuições à Geologia do Rio Grande do Sul e de Santa Catarina /Andréa Ritter Jelinek e Carlos Augusto Sommer, organização - Sociedade Brasileira de Geologia - Porto Alegre : Compasso Lugar-Cultura, 2021.

504 p., il. col.

ISBN E-book: 978-65-89013-03-7

https://doi.org/10.29327/537860

1. Geologia 2.Sociedade Brasileira de Geologia 3. Coletâneas de textos I. Jelinek, Andréa Ritter II. Sommer, Carlos Augusto III. Título

Bibliotecária Responsável: Catarina Strapação Guedes Vianna CRB-10/2469

Índices para catálogo sistemático:

1. Geologia 551 


\title{
Folhelho Lontras, uma Lagerstatte do Paleozoico brasileiro
}

\author{
Lucas Del Mouro ${ }^{1 *}$, João Henrique Zahdi Ricetti ${ }^{2,3}$, \\ Luiz Carlos Weinschütz ${ }^{3}$, Mírian Liza Alves Forancelli Pacheco ${ }^{4}$ \\ ${ }^{1}$ Departamento de Geologia, Universidade Federal de Santa Catarina \\ ${ }^{2}$ Instituto de Geociências, Universidade Federal do Rio Grande do Sul \\ ${ }^{3}$ Centro Paleontológico da Universidade do Contestado, Universidade do Contestado \\ ${ }^{4}$ Laboratório de Estudos Paleobiológicos, Universidade Federal de São Carlos
}

*autor correspondente: lucas.delmouro@gmail.com

\section{INTRODUÇão}

0 estudo dos fósseis é fundamental para o entendimento da evolução da vida em resposta às modificações do planeta durante o tempo geológico. São eles, em especial os que possuem partes moles preservadas, cruciais para avaliarmos as mudanças ocorridas no planeta e modelarmos hipóteses para as alterações futuras. No entanto, os fósseis de corpos moles são estatisticamente raros e normalmente estão associados nos conhecidos depósitos KonservatLagerstatten (Seilacher, 1970). Esses últimos são definidos como depósitos fossilíferos com preservação incomum e, segundo Cardoso et al. (2020), apesar da importância dos Konservat-Lagerstatten, suas ocorrências são escassas e restritas, delimitadas por grupos de estratos com idades, contexto paleodepositional e localização geográfica similar. Portanto, a identificação desses tipos de depósitos é extremamente rara.

No Brasil, embora haja abundantes exposições fossilíferas, tínhamos reconhecidamente até o final da década de 1990, apenas os estratos da Formação Santana e Romualdo, Bacia do Araripe, como depósitos Konservat-Lagerstatte. Este cenário vem-se modificando, em especial pelo contínuo relato de fósseis com preservação incomum no Intervalo Fossilífero Folhelho Lontras (IFFL), Carbonífero-Permiano da Fm. Campo Mourão, Bacia do Paraná.

Descoberto em 1908 por Jay Backus Woodworth e Euzébio Paulo de Oliveira, durante a expedição por camadas glaciais no sul do Brasil, o IFFL é composto por uma diversa e bem preservada associação fossilífera. Esse sítio marinho fossilífero, hoje encontrado no Afloramento 
Campaleo, compreende uma combinação de diferentes tipos preservação, incluindo partes duras e tecidos moles de organismos aquáticos (peixes, poríferos e amonóides), assim como de biotas terrestres (insetos e plantas).

\section{HiSTÓRIA DA DESCOBERTA DO LAGERSTATTE}

A história do Folhelho Lontras e de seus magníficos fósseis começa no início do século XX, quando expedições geológicas financiadas pelos governos brasileiro e estadunidense deram início a investigações por depósitos minerais e por registro glaciais (Mouro et al., 2018).

Financiados pelo Shaler Memorial Fund, um fundo de financiamento à pesquisa criado por alunos e por admiradores do professor da Universidade de Harvard, o geólogo Nathaniel Southgate Shaler, Jay Backus Woodworth e o geólogo brasileiro Euzébio Paulo de Oliveira percorreram diversas localidades dos estados de São Paulo, do Paraná e de Santa Catarina, em 1908. Dentre as localidades visitadas, descobriram e descreveram uma camada de folhelhos negros fossilíferos no bairro de Bela Vista, ao sul da cidade de Rio Negro, no Paraná, cuja extensão, na época, compreendia, também, o atual município de Mafra, em Santa Catarina. Atualmente, esta camada é cronocorrelata à camada do Afloramento Campaleo, no Intervalo Fossilífero do Folhelho Lontras.

Cerca de 200 amostras da expedição de Euzébio de Oliveira em 1908, foram enviadas por Orville Derby para o Museu do Estado de Nova Iorque (New York State Museum), onde estão armazenadas até hoje e resultaram na primeira publicação científica acerca do IFFL (veja Ruedemann, 1929). Além da relevância científica, esses exemplares possuem enorme valor histórico, tendo em vista que o afloramento visitado por Wo- odworth e por Oliveira foi encoberto pela construção de moradias populares. Apesar da abundância e da diversidade de fósseis registradas para o Folhelho Lontras, em Mafra, após a precursora publicação de Ruedemann, complementada por Oliveira (1930), poucas menções aos fósseis foram feitas, durante as décadas seguintes (e.g. Carvalho, Miranda \& Alvin, 1942; Schneider et al., 1974; Rösler, 1985), até a descrição da primeira espécie do Intervalo Fossilífero do Folhelho Lontras, i.e., Santosichtyes mafrensis Malabarba, 1988, seguida da tese de Richter sobre a paleoictiofauna do Folhelho (Richter, 1991).

Em 1997, durante o processo de terraplenagem para instalação de uma empresa na região industrial ao sul da cidade, ainda em seu perímetro urbano, estratos do IFFL foram encontrados. 0 achado culminou em uma mobilização de órgãos de fiscalização, do poder executivo, da sociedade científica e da comunidade local com repercussão nacional. Um movimento da Prefeitura de Mafra decretou como de interesse público para fins de preservação do Patrimônio Natural uma propriedade a 300 metros da área de instalação da empresa, antigamente explorada como lavra para indústria ceramista, onde o Folhelho Lontras e seu intervalo fossilífero encontravam-se aflorantes. Esta área foi posteriormente desapropriada e disponibilizada para realização de pesquisas, sob os cuidados do Centro Paleontológico da Universidade do Contestado. Nascia assim o afloramento Campaleo (Fig. 1; Hamel, 2005; Mouro et al., 2014a; Weinschütz et al., 2019). A partir deste momento, a pesquisa geocientífica do Folhelho Lontras se tornou mais constante e a qualidade de preservação de seus fósseis, bem como a riqueza de sua paleobiota, sendo paulatinamente conhecida e, atualmente, considerada um Fóssil Largesttäte do Paleozoico Superior (e.g. , Scomazzon et al., 2013; 


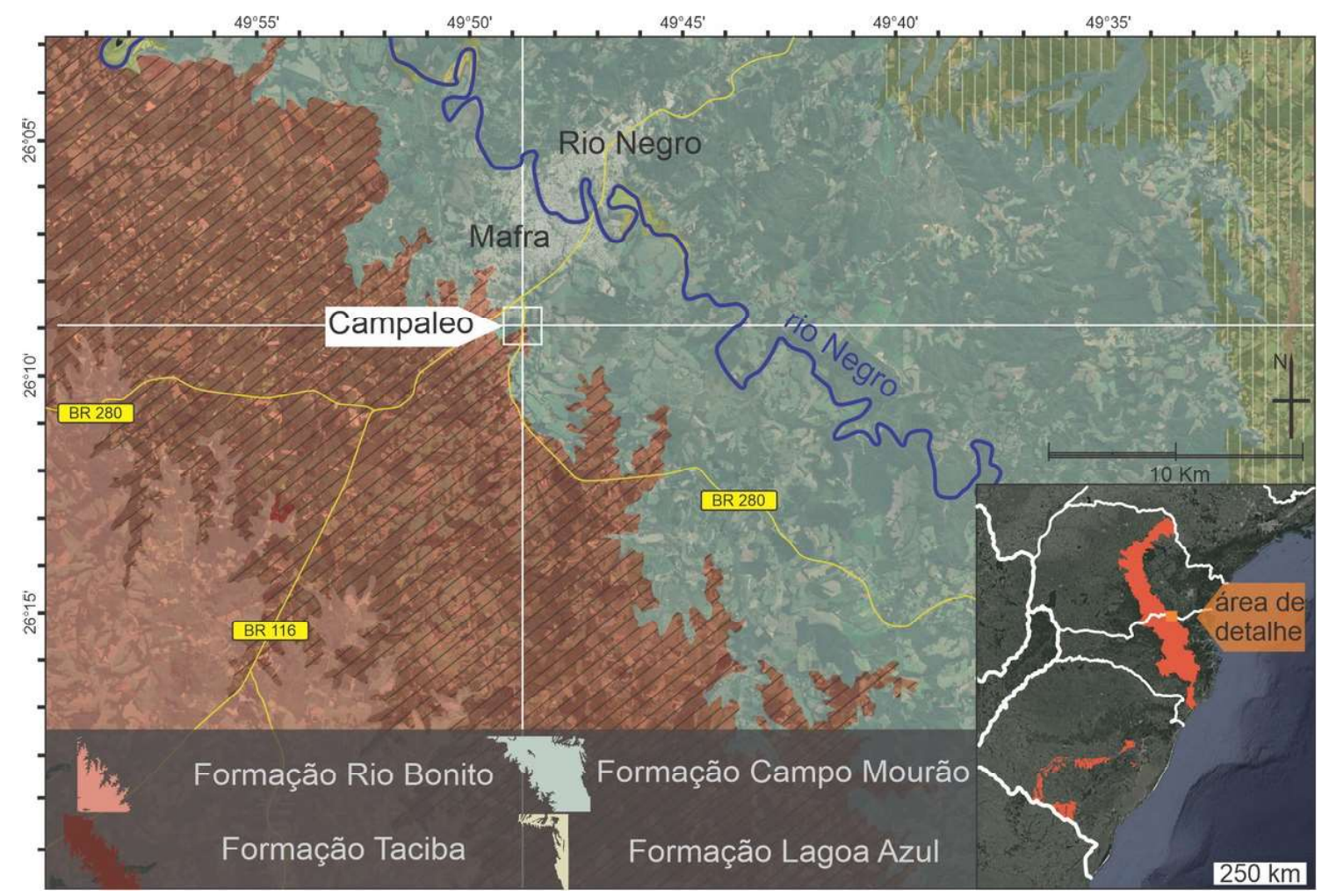

Figura 1 - Mapa de localização do Afloramento Campaleo (IFFL). Em detalhe, a localização das unidades Carboníferas-Permianas aflorantes nos estados do sul do Brasil.

Iannuzzi et al., 2014; Ricetti et al., 2014a; Mouro et al., 2016, 2017, 2020).

\section{ConTeXto geológico}

Localizado no topo da Formação Campo Mourão, no Grupo Itararé, da Bacia do Paraná (França \& Potter, 1988; Weinschütz \& Castro, 2004), o Folhelho Lontras é considerado um marco estratigráfico da bacia, denotando um evento de máxima transgressão. Segundo Buso et al. (2019), esse intervalo corresponde ao segundo Trato de Sistema de Degelo (DST2 from sub-cycle II of Cycle II, a 3rd-order or high-frequency, orbitaldriven glacial cycles), o qual compreende depósitos marinhos pró-glaciais e representa ciclos de degelo, resultando no aumento relativo do nível do mar. O DST2 corresponde à sedimentação marinha pró-glacial, oriunda de longínquas plumas turbidíticas e de sedimentos hemipelágicos (Buso et al., 2019).

Regionalmente, o Folhelho Lontras possui, aproximadamente, $50 \mathrm{~m}$ de espessura, compreendendo uma série de folhelhos várvicos, que se alternam com pacotes de siltitos e de argilitos (Weinschütz \& Castro, 2005). Essa sucessão tem um afinamento textural e uma redução de clastos caídos para o topo, marcando a transgressão, ligada à deglaciação, que culmina na inundação máxima da bacia (Weinschütz \& Castro, 2005).

Nos últimos anos, a idade atrelada ao Folhelho Lontras tem sido tema de discussão. Enquanto Cagliari et al. (2016), Buso et al. (2019), Griffis et al. (2018) e Griffis et al. (2019), baseados em datação de U-Pb em zircão, assinalaram que o topo do Grupo Itararé corresponde, geocronologicamente, ao final do Carbonífero Superior, a maioria dos métodos bioestratigráficos, baseados em dados palinológicos e em conodontes (zonas Vittatina costabilis e Mesogondolella spp.), posicionaram o Folhelho Lontras na idade Cisuraliana (Permiano Inferior) (veja Petri \& 
Souza, 1993; Dino \& Rösler, 2001; Souza, 2005; Holz et al., 2010; Scomazzon et al., 2013; Wilner et al., 2016a). Essa última foi ratificada por dados de $\mathrm{Rb}-\mathrm{Sr}$ detrítico em amostras oriundas do Afloramento Campaleo (Koester et al., 2016). Essa indefinição, a respeito da idade do Folhelho Lontras, sugere a possibilidade de um degelo diácrono do Grupo Itararé, como já visto na Bacia de Paganzo, na Argentina (Moxness et al., 2018). No entanto, considerando o grau de confiança da datação absoluta, é plausível posicionar o Folhelho Lontras na idade Pennsilvaniana.

O Afloramento Campaleo (S $26^{\circ} 09^{\prime}$ 30.22", W 4948' 52.82") (Fig. 1) está localizado às margens da rodovia BR-280, a cerca de $2 \mathrm{~km}$ do trevo com a BR-116, na região urbana da cidade de Mafra, em Santa Catarina. A base do afloramento é composta por 1 $\mathrm{m}$ de siltito bioturbado, sobreposto pelos 1,10 m de folhelho negro macrofossílifero. Acima, segue um ritmito não fossilífero de 7 m. Weinschütz (2010) subdividiu o folhelho fossilífero em quatro níveis, denominados, da base para o topo, 1, 2, 3 e 4 (Fig. 2). Cada nível foi dividido em subníveis, referentes à forma de desplacamento e de acamamento das camadas, sendo reflexo direto de variações da deposição e/ou de processos diagenéticos. Assim, temos: nível 1 ( $A, B, C, D)$; nível 2 (A, B); nível 3 (A, B, C, D); e nível 4 (A, $B)$. É importante ressaltar que as variações deposicionais, dentro da granulometria do folhelho, são sutis.

\section{Paleobiota do Folhelho Lon- TRAS}

Desde a sua redescoberta, em meados da década de 1980, o conhecimento, a respeito da assembleia fossilífera do Folhelho Lontras, vem sendo aprofundado e ampliado. Uma síntese de seu conteúdo fossilífero é, aqui, apresentada, conforme sua afinidade com as grandes áreas da pesquisa paleontológica: paleovertebrados, paleoinvertebrados, paleoflora, microfósseis e icnofósseis (Figs. 3-9).

\section{Paleovertebrados}

Peixes: ao menos, duzentos espécimes completos de peixes actinopterígios, incluindo juvenis e adultos, foram resgatados. As espécies Santosichtyes mafrensis (Malabarba, 1988) e Roslerichthyies riomafrensis (Hamel, 2005) foram descritas no IFFL, além de outras, descritas e não publicadas por Richter (1991). A constante coleta possibilita, ainda, a descrição de novas espécies da paleoictiofauna do Folhelho Lontras (Fig. 3A-3B). Segundo Hamel (2005), os peixes fósseis do IFFL são encontrados, normalmente, comprimidos na matriz, mas também podem ser recuperados com suas características tridimensionais pouco alteradas, em concreções fosfáticas. Por outro lado, exemplares, associados à Classe Chondrichthyes, são encontrados apenas fosfatizados e, majoritariamente, na forma de dentes isolados (Pauliv et al., 2014). Ocasionais escamas ganóides também são encontradas, isoladas, nas lâminas do folhelho.

\section{Paleoinvertebrados}

Annelida: entre os subníveis 2B e 3B, foram descobertos cerca de 30 elementos mandibulares de poliquetos. Normalmente, esses escolecodontes são encontrados isolados no plano de acamamento, assim como dentro de concreções fosfáticas, em que a ocorrência de um possível corpo de poliqueto, com estruturas cilíndricas segmentadas e cerdas, foi reportado (Fig. 4A-4B) (Ricetti \& Weinschütz, 2011; Ricetti et al., 2014; Mouro, 2017). Atualmente sob estudo, apresentam, a princípio, composição carbonácea.

Brachiopoda: um dos primeiros gru- 


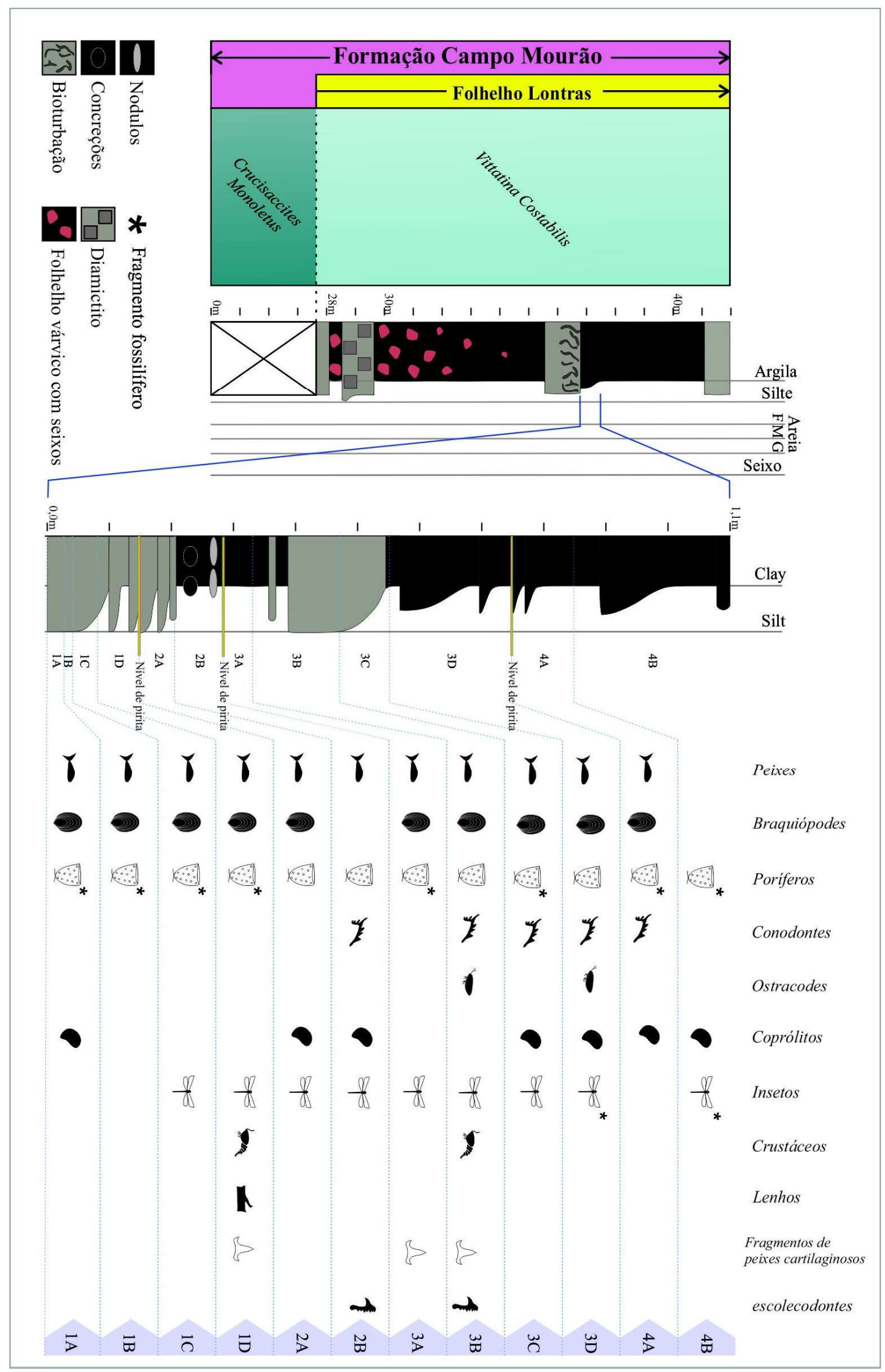

Figura 2 - Detalhamento estratigráfico do intervalo fossilífero do Folhelho Lontras (Formação Campo Mourão, na Bacia do Paraná) e sua associação fossilífera (modificado de Mouro et al., 2020). 


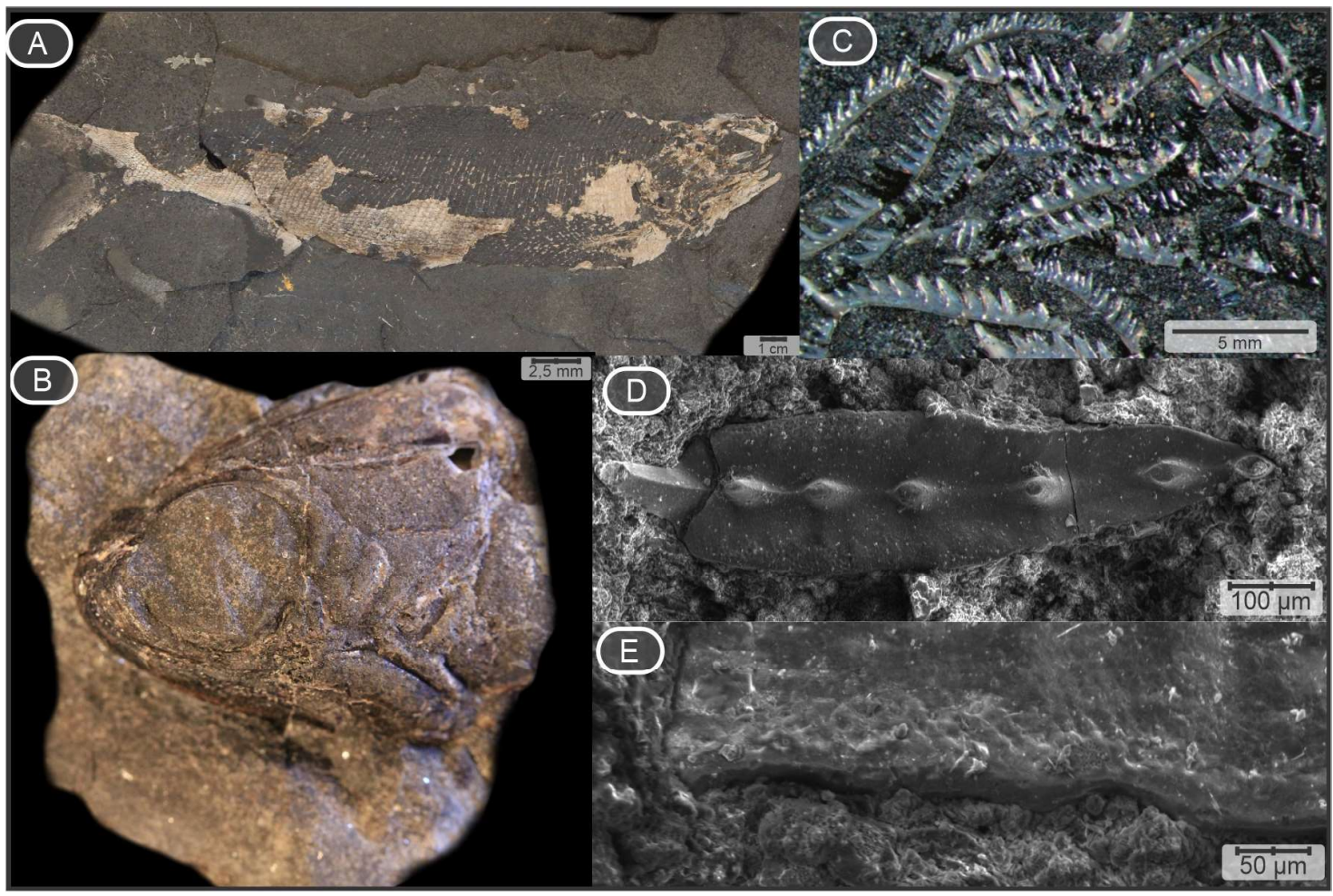

Figura 3 - Fósseis associados a vertebrados e a "proto-vertebrados": (a-b) Espécimes de peixes actinopterígios (CP.V 5202a, retirado de Mouro et al., 2020); (c-e) Aparatos mandibulares de conodontes.

pos a ser identificado e descrito nas camadas do Folhelho Lontras, durante a expedição de Eusebio de Oliveira e de James Woodworth, em 1908 (veja Woodworth, 1912). Mais de três centenas de espécimes de braquiópodes já foram coletados, sendo, na sua grande maioria, indivíduos de Langella imbituvensis, de Chonetes rionegrensis, de Biconvexiella roxoi, de Quinquenella? sp., de Beecheria? sp. e de Orbiculoidea guaraunensis (Fig. 4C-4D) (Oliveira, 1930; Neves et al., 2017). Mouro (2017) descreveu a ocorrência isolada de diminutos espécimes fosfatizados e querogenizados em alguns dos subníveis do Afloramento Campaleo. Todos eles se encontram paralelos ao plano de acamamento.

Crustacea: Adami-Rodrigues et al. (2012) identificaram e descreveram corpos e fragmentos de indivíduos da Subclasse Eumalacostraca (Fig. 5A). Esses espécimes, preservados carbonificados, impressos ou em concreções, indicam uma assembleia autóc- tone marinha, preservada em soterramento rápido ou em ambiente de baixa energia, com fundo anóxico.

Insecta: a ocorrência de fósseis dessa classe nos sedimentos do Folhelho Lontras já é conhecida, desde a década de 1990, e, talvez, junto com os elementos conodontes, os insetos compreendam as principais descobertas paleontológicas do Afloramento Campaleo, com efeitos diretos no entendimento da evolução biológica. Normalmente, eles são encontrados preservados entre os subníveis $1 \mathrm{~A}$ e $3 \mathrm{~A}$, em três maneiras: comprimidos e piritizados, carbonizados ou fosfatados. Entre as ordens identificadas, destaque para Blattodea e para Grylloblattodea, que representam mais de 100 espécimes corpóreos encontrados (Martins-Neto, 2005; Pinto \& Sedor, 2000; Ricetti et al., 2016). Aproximadamente, 54\% da fauna é composta pela espécie de Phyloblattidae Anthracoblattina mendesi Pinto \& 
Sedor, 2000, descrita para o IFFL e revisada por Ricetti et al. (2016). Os detalhes de preservação destes espécimes são tamanhos, que se torna possível verificar flagelos nas antenas, escleritos torácicos, assim como padrões epicuticulares (Ricetti et al., 2016) (Fig. 5B, Fig. 9C-9D). Mouro et al. (2020) reportaram a preservação de fibras musculares submilimétricas em alguns espécimes de insetos (Fig. 9E-9H). Ainda sobre fósseis, associados à Classe Insecta, o mais antigo casulo larval da Ordem Trichoptera foi encontrado e descrito no Folhelho Lontras (Mouro et al., 2016) (Fig. 5C). Esses fósseis, não, apenas, aumentaram o tempo de existência do hábito de fazer casulos dos Trichoptera, do Jurássico para o Carbonífero Superior, mas, também, lançaram uma luz sobre a ecologia e sobre o comportamento dos tricopterídeos nos estágios iniciais de evolução, que teria iniciado em ambiente marinho calmo e subtidal.

Porifera: no IFFL, são encontradas as melhores preservações de poríferos do Brasil. Mouro et al. (2014) (Figs. 6A e 6B e 9A e 9B) identificaram corpos articulados e bem delimitados de hexactinellideos, descrevendo a primeira espécie paleozoica brasileira, Microhemidiscia greinerti. Em 2017, o mesmo autor divulgou a ocorrência de um possível indivíduo demospongídeo, que havia sido coletado por Oliveira (1927) e que se encontrava depositado no acervo do New York State Museum. Ainda a respeito das esponjas, a partir de estudos tafonômicos e geoquímicos, Mouro et al. (2017) estabeleceram duas tafofácies do grupo nos subníveis do Afloramento Campaleo. Em 2020, foi reportada a presença de partes moles preservadas de poríferos, o que reforçou as condições únicas e especiais desse pacote sedimentar.

Ammonoidea: Weinschütz et al. (2018) comunicaram o achado dos primeiros exemplares de Ammonoidea no IFFL, sendo considerados, também, os primeiros da Bacia Sedimentar do Paraná. Os dois espécimes apresentam forte compactação e estão preservados parcialmente, por piritização (espira externa), parcialmente, por fosfatização (espira central) (Fig. 6E). Embora estejam em estudo, uma análise preliminar apontou afinidades com o gênero Uraloceras, descrito no Permiano, nos Montes Urais (Cazaquistão).

\section{ICNOFÓSSEIS}

Nos subníveis inferiores do Afloramento Campaleo, foram identificadas algumas ocorrências esparsas de coprólitos heteropolares e de enteróspiras. Os coprólitos apresentam formato arredondado e cilíndrico, com médias de $24 \mathrm{~mm}$ de comprimento, de $13 \mathrm{~mm}$ de largura e de 6 mm de espessura (Fig. 6C) Em determinadas amostras, é possível observar um acamamento interno concêntrico, e, em outras, pode-se notar fissuras radiais (Muller et al., 2017). As enteróspiras, que são exemplares de intestinos fossilizados de tubarões, possuem formato cilíndrico e comprimento médio de $22 \mathrm{~mm}$, largura média de $11 \mathrm{~mm} \mathrm{e}$ diâmetro médio de 5 mm (Fig. 6D).

\section{Paleoflora}

Fragmentos carbonizados milimétricos a centimétricos são facilmente reconhecidos no Folhelho Lontras (Mouro, 2013) (Fig. 7). Eles normalmente estão associados aos demais fragmentos fossilíferos, como dentes, escamas, espículas e aparelhos mandibulares. Gnaedinger et al. (2012) e Urban et al. (2012) identificaram a ocorrência de espécimes de lenhos Agathoxylon Hartig e Abietopitys Kräusel. Quando nos voltamos a fragmentos micrométricos, Mouro et al. (2012) e Mouro (2013) reportaram a ocorrência de fitoclastos não opacos e opacos, assim como a presença de grãos de pólen e de esporos (Fig. 7E-7G). Ainda, em Mouro et al. 


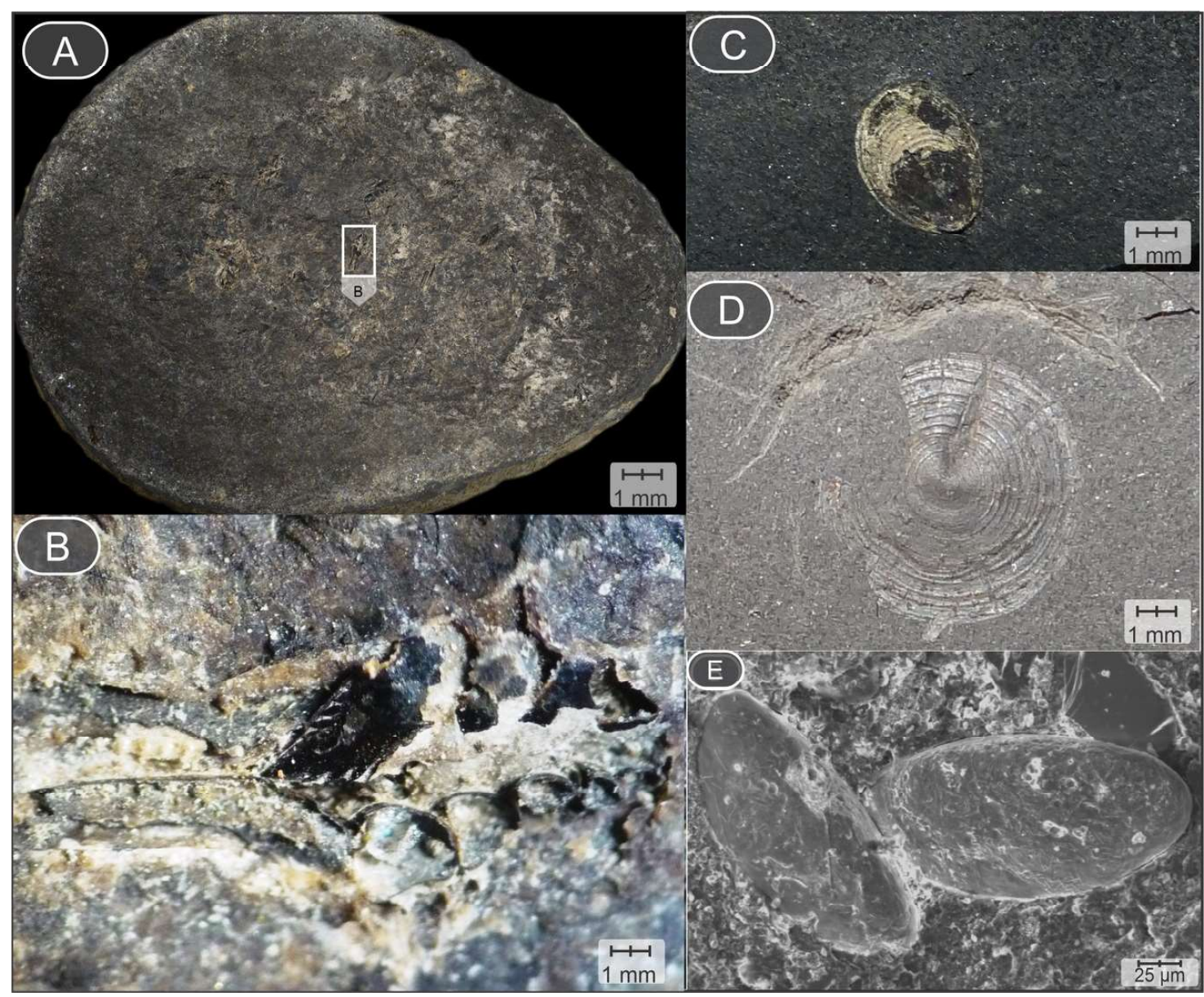

Figura 4 - Biota de paleoinvertebrados: preservações associadas a anelídeos: (a) Uma possível impressão de somitos; (b) Aparelhos mandibulares de escolecodontes; (c-d) Braquiópodes; e (e) Ostracodes.

(2020), é apresentada uma possível resina vegetal (Fig. 7C).

\section{MiCROFÓSSEIS}

Conodonta: dezenas de aparatos articulados e centenas de elementos isolados, do gênero Mesogondolella spp., foram recuperados em cinco subníveis do Afloramento Campaleo (Fig. 3C-3E) (veja Scomazzon et al., 2013; Wilner et al., 2016a). Os espécimes preservados são encontrados fosfatizados (por fosfato de cálcio), paralelos ao plano de acamamento e com alternância entre elementos ramiformes e P1 (Mouro et al., 2020).

Foraminifera: o primeiro registro desse grupo nas camadas do IFFL foi realizado por Lopes (2016). Segundo o autor, a morfologia externa indicaria a ocorrência de um foraminífero bentônico aglutinante. Contudo, as características também morfométricas permitem supor a ocorrência de ovos de invertebrados. Pigão \& Mouro (2019) ratificaram a ocorrência do filo, ao identificar foraminíferos em lâminas petrográficas do subnível 3B (Fig. 8).

Ostracoda: Kallen et al. (2014a, 2014b) registraram a presença de microcrustáceos da classe Ostracoda. Esses microfósseis possuíam comprimento médio de $175 \mu \mathrm{m}$ e largura média de $85 \mu \mathrm{m}$. A variação morfológica observada pode indicar estágios ontogenéticos ou a ocorrência de mais de uma espécie. As carapaças geralmente possuem composição fosfática (Cálcio) e são encontradas articuladas, bem 


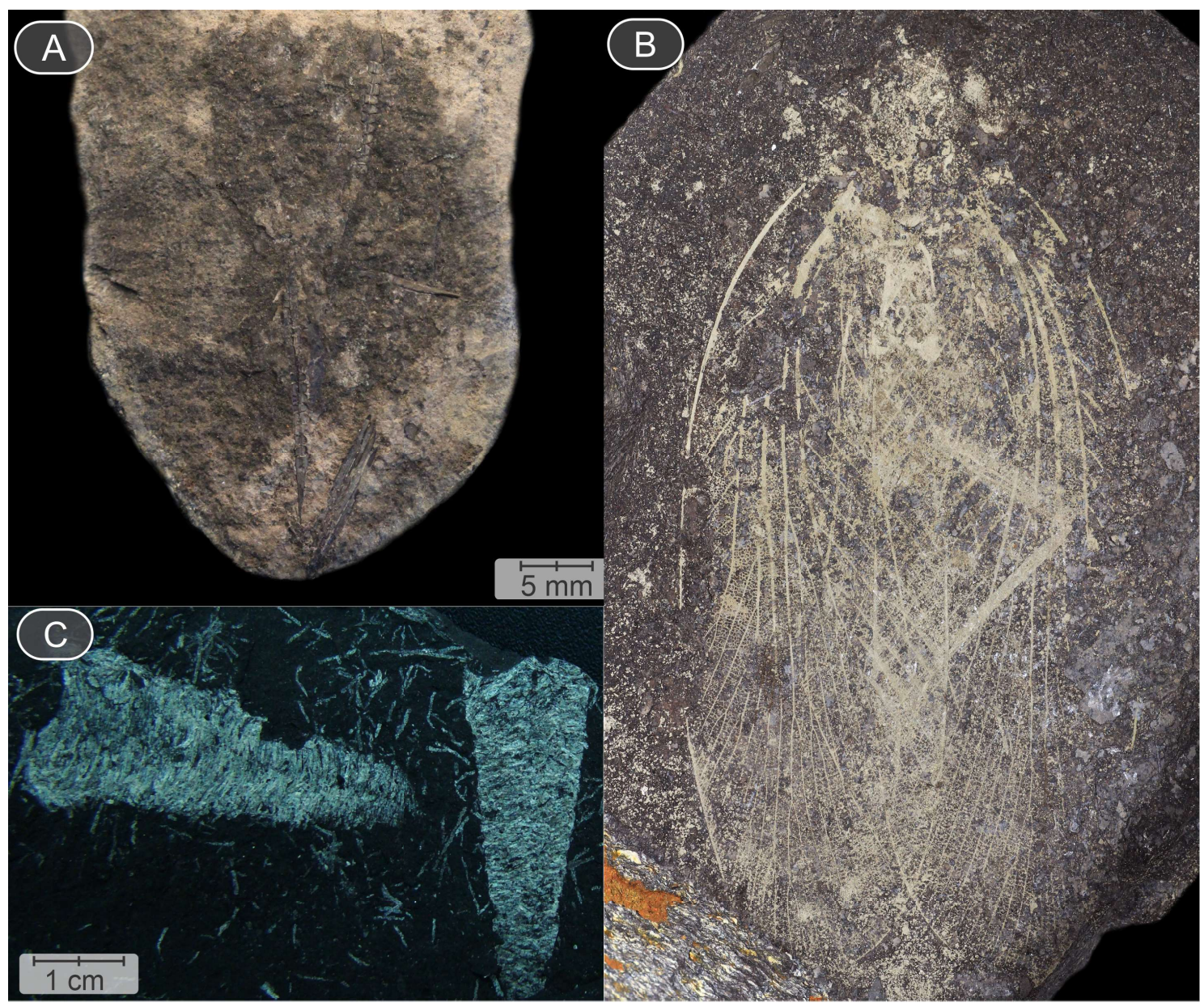

Figura 5 - Biota de paleoinvertebrados: (a) Espécime de Malacostraca, dentro de concreção (CP.I 887a, retirado de Mouro et al., 2020); (b) fóssil bem preservado de Anthracoblattina mendesi (CP.I 2182, retirado de Ricetti et al., 2016); e (c) casulos larvais de Trichoptera (CPE 7811, retirado de Mouro et al., 2016).

preservadas, com coloração âmbar a branca e pouco ornamentadas (Fig. 4E).

\section{Paleoambiente, paleoecologia E PRESERVAÇÃO}

Entre o final do Carbonífero e o início do Permiano (Cisuraliano), o paleocontinente Gondwana apresentava a toda sua região austral, sob influências deglaciais, relacionadas ao final da Era do Gelo do Paleozoico Tardio (Late Palaeozoic Ice Age). Apesar das discussões, a respeito do padrão de distribuição das camadas de gelo na porção sul do Gondwana, sua influência está muito bem registrada nas unidades do Grupo Itararé, na Bacia do Paraná (Scotese, 1997;
Ziegler et al., 1997; Buggisch et al., 2011; Isbell et al., 2012; Montañez \& Poulsen, 2013; Fedorchuk et al., 2018, 2019). Recentes trabalhos indicam que a porção sul do que, hoje, é o Brasil, durante a passagem CarboníferaPermiano, apresentava uma fisiografia e uma morfologia de lobos glaciais, formando vales de sistema fjord, semelhantes aos vistos, atualmente, no Chile e na Nova Zelândia (Lopes et al., 1986; Lavina \& Lopes, 1987; Dias, 1993; Machado, 1994; Santos et al., 1996; Holz et al., 2010; Silveira, 2000; Vesely et al., 2015; Tedesco et al., 2016, Mouro et al., 2017, 2020). Neste mesmo cenário, Fallgatter \& Paim (2017) reconheceram três ciclos glaciais e a presença de um paleovale entre Alfredo Wagner e Vidal Ramos, na porção 

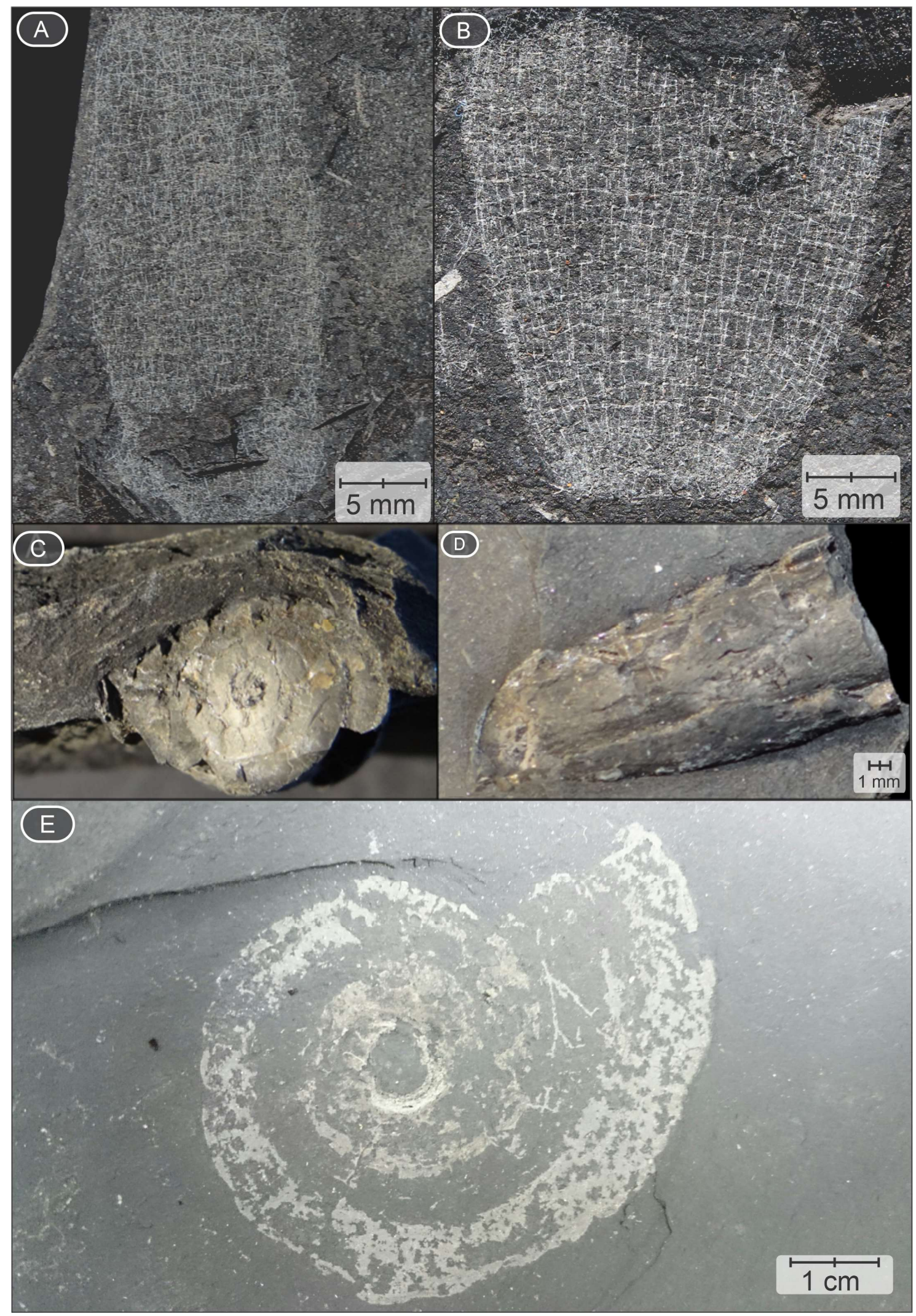

Figura 6 - Paleoinvertebrados e icnofósseis: (a-b) exemplares de poríferos Microhemidiscia greinerti (CPI 450 e 451, retirados de Mouro et al., 2014). Exemplares de icnofósseis: (c) enteróspira e (d) coprólito heteropolar. (e) Exemplar de amonoide. 

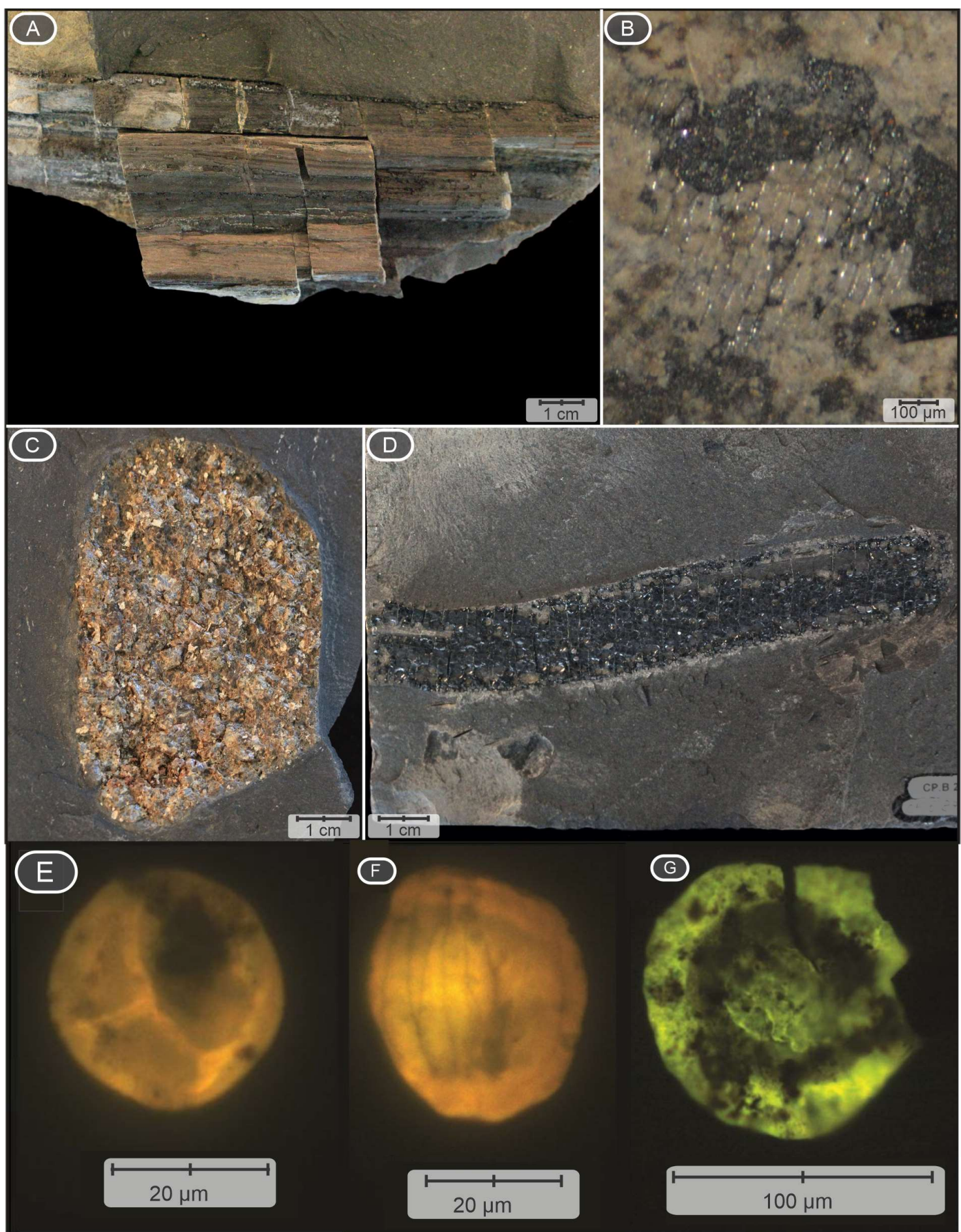

Figura 7 - Paleoflora do IFFL: (a) Lenho (CP.B 7196); (b) Impressão de cutícula (CP.M 122); (c) Possível âmbar (CP.E 6521b); (d) Caule carbonizado; (e-f) Pólens; e (g) Alga prasinófita.

central do estado de Santa Catarina, que estaria conectado, a norte, com uma grande baia, em Rio do Sul (veja Canuto, 1999). Ainda, segundo esses autores, no final do primeiro ciclo glacial, enquanto a geleira recuava para SE e o nível marinho relativo aumentava, um profundo sistema fjord foi estabelecido. Os sedimentos depositados, durante o fim deste primeiro ciclo, correspondem ao principal marco estratigráfico do Grupo Itararé, o Fo- 


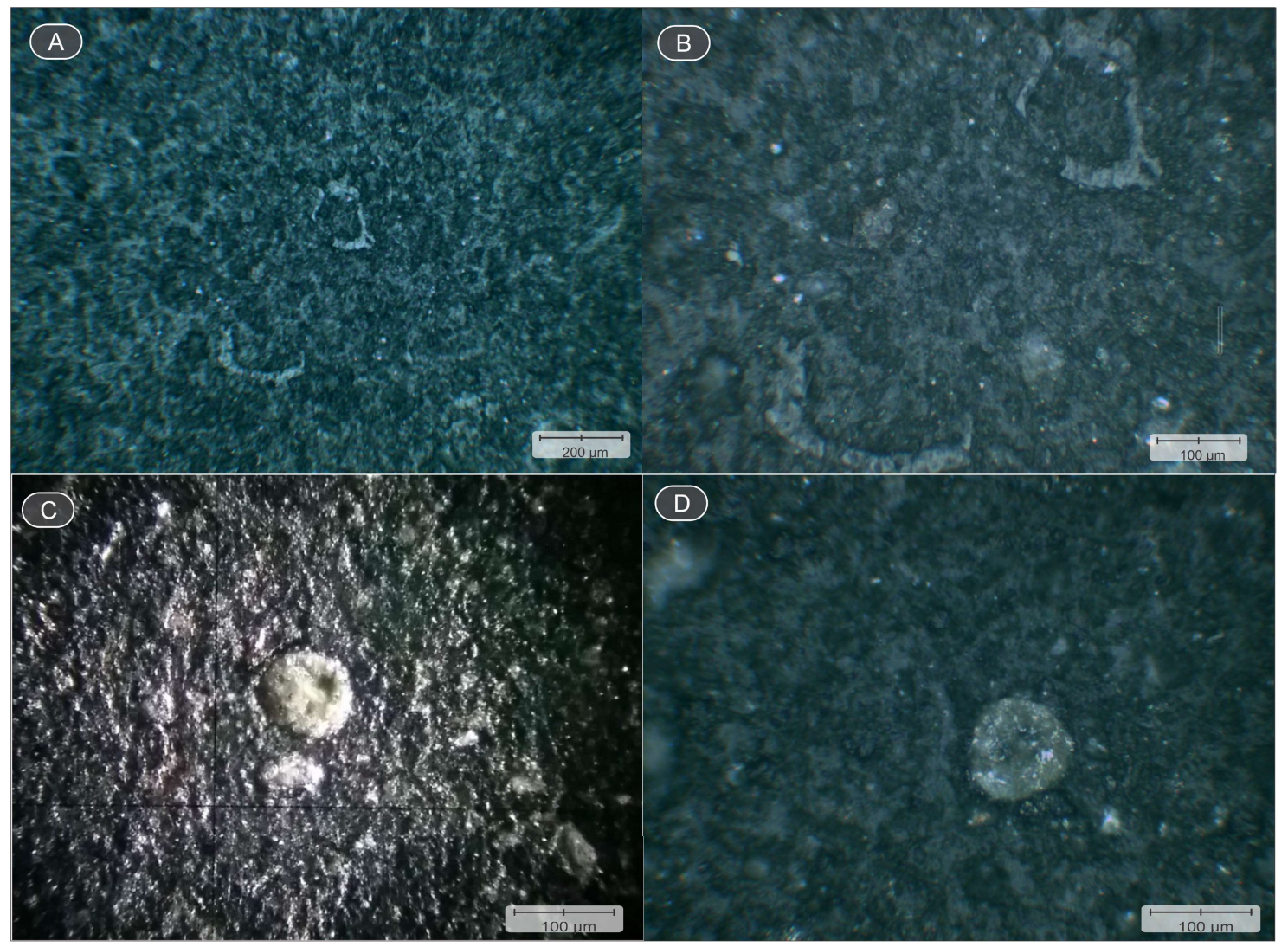

Figura 8 - Foraminíferos do IFFL em lâmina petrográfica: (a-b) espécimes multicameras; e (c-d) espécimes globulares (retirado de Pigão \& Mouro, 2019).

lhelho Lontras (Schneider et al., 1974; França \& Potter, 1988).

Apesar da ausência de fósseis na maioria das ocorrências do Folhelho Lontras, a medida em que o processo de degelo prevalecia no norte do estado de Santa Catarina, as condições climáticas favoráveis possivelmente propiciaram o estabelecimento de um hotspot de biodiversidade, como visto, atualmente, nos fjords da Nova Zelândia, e assinalado no horizonte, no sítio Campaleo. A partir de uma análise multiproxy (geoquímica orgânica e inorgânica, paleontologia e palinologia), Mouro et al. (2017) assinalaram características de um ambiente marinho restrito, com profundidades entre $200 \mathrm{~m}$ e 400 $\mathrm{m}$ e, provavelmente, um embaiamento, causado por frente de geleira. Ademais, reconheceram dois tratos de sistema: trato de sistema transgressivo (TST), nos subníveis $1 \mathrm{~A}, 1 \mathrm{C}$ a $3 \mathrm{~B}$, e trato de sistema de mar alto
(HST), nos subníveis 1B, 3B a 4B. A partir destas análises, os autores observaram uma recorrente euxinia na zona fótica, assim como a predominância de condições anóxicas/ euxínicas no bentos. Essas condições podem estar relacionadas à ausência de ação de marés, uma vez que a presença de micromarés é esperada em paleoambientes, relacionados a fiordes (veja Austin \& Scourse, 1997; Allison et al., 1998; Wells et al., 2005). Contudo, a presença de poríferos autóctones assinala, ao menos, rápidos momentos de oxigenação, portanto não se descarta a possibilidade de micromarés de baixíssima intensidade, como visto em mares epicontinentais do Carbonífero na Europa.

Portanto, combinando-se o complexo contexto paleoambiental com as condições paleoclimáticas e paleogeográficas, é aceitável assinalar o IFFL como uma profunda baía de paleofjord (Mouro et al., 2020). 

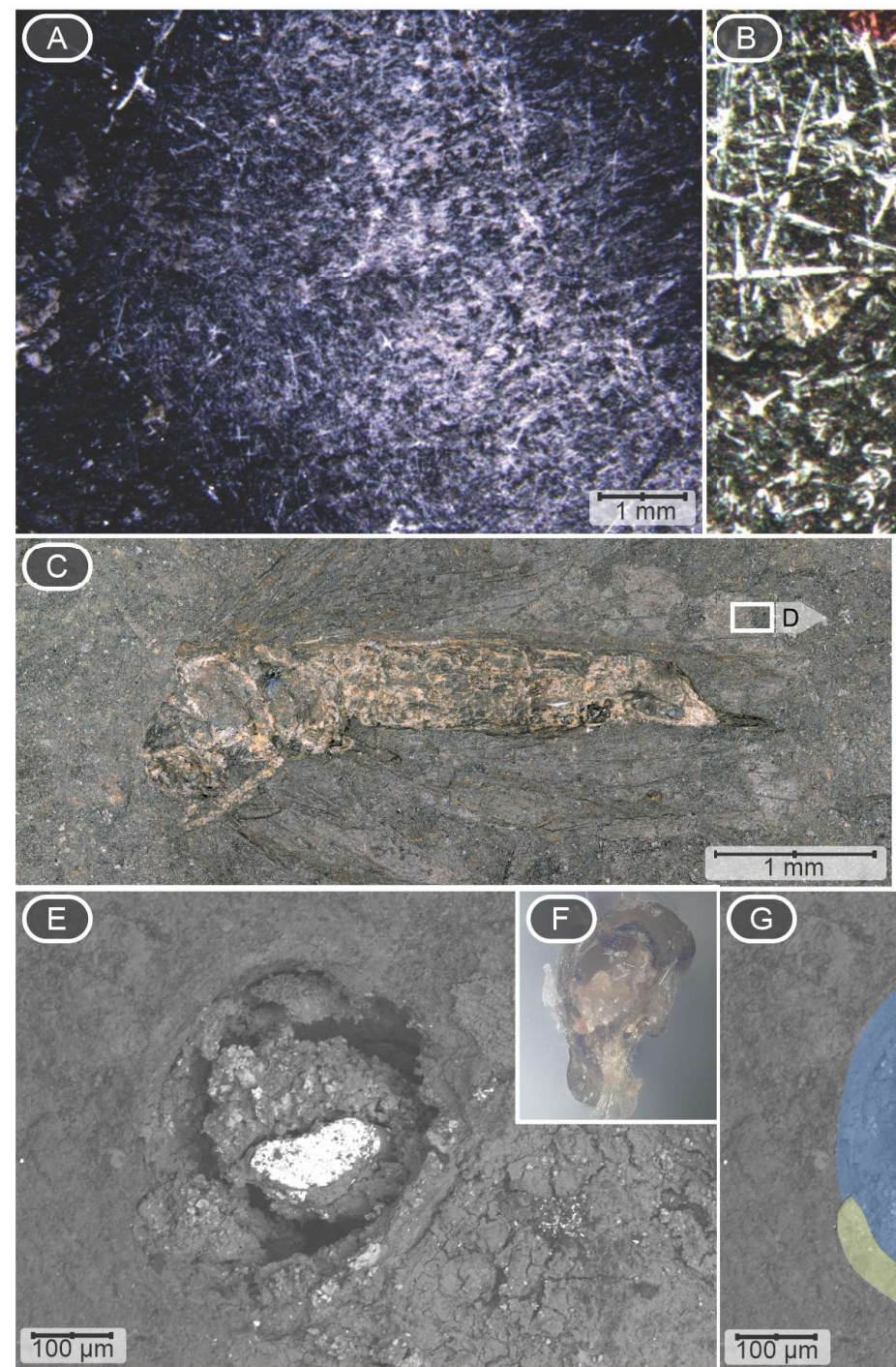
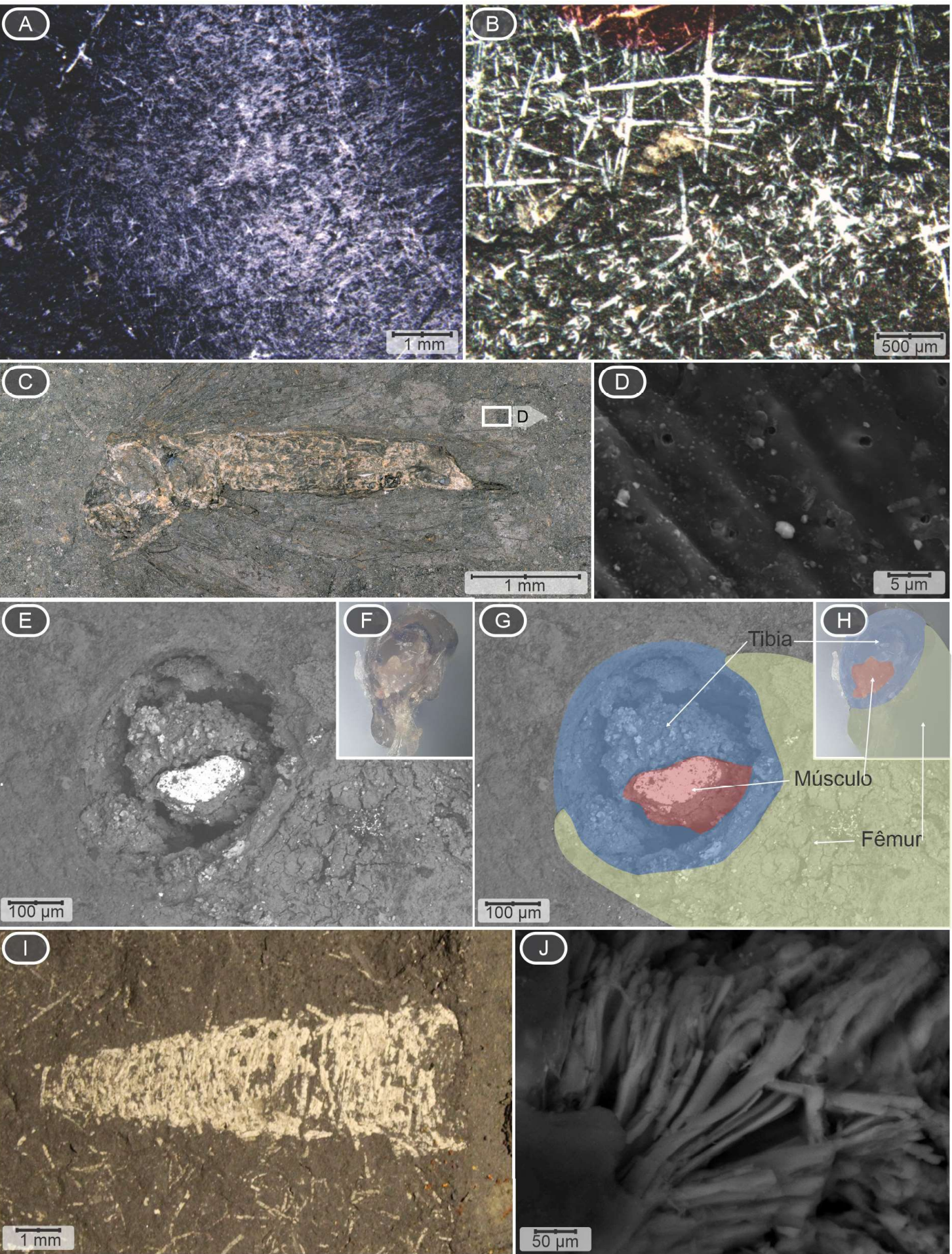

Figura 9 - Preservação incomum no IFFL: (a) Hexactinellídeo com possível epiderme; (b) Macroscleras de Hexactinelídeo como microsclera hemidisco; (c-d) Inseto tridimensional fosfatizado (CP.E 3243 a); (e-g) Articulação femur-tíbia com tecido muscular preservado (CP.I 2276b); (f-h) Articulação femur-tíbia e músculo tarsal; (i) Casulo larval de Trichoptera; (h) Detalhe da estrutura semelhante à seda, encontrada no casulo larval (imagem de MEV).

Sistemas estuarianos semelhantes são observados em outras paleobiotas Carboníferas-Permianas de excelente preservação, como Hamilton Fossil-Lagerstatte (Cunningham et al., 1993), Mazon Creek (Kuecher et al., 1990), assembleia Kinney Brick (Ar- 
cher \& Feldman, 1990) e Folhelho Lawrence (Zidek, 1992).

0 Folhelho Lontras é categorizado como Lagerstatte, devido à ocorrência de diferentes tipos de preservação, de amplo espectro tafonômico, incluindo a presença de partes duras e moles de organismos aquáticos e terrestre, como visto em outros importantes Lagerstatten (e.g. Mazon Creek) (Fig. 9) (Mouro et al., 2020). 0 IFFL, mesmo apresentando condições favoráveis ao processo de piritização, contém poucos fósseis piritizados (veja Mouro et al., 2017), haja visto que sua maioria está preservada como compressões carbonáceas ou fosfáticas. A qualidade da preservação pode estar diretamente relacionada à grande abundância de matéria orgânica em condições redutoras, como apontam os dados geoquímicos e sedimentológicos do IFFL (Mouro et al., 2017; Mouro et al., 2020). Apesar da excelente preservação, existem poucas evidências da ação de microorganismos (EPS ou biofilmes) no decaimento e na preservação dos espécimes, como tem sido visto em outros Lagerstatten (Osés et al., 2016). Mas isso se deve à falta de estudos mais detalhados sobre esta ação no IFFL. Desta forma, o Folhelho Lontras, em Mafra, é uma unidade promissora, para investigações mais aprofundadas sobre a geomicrobiologia e sobre a fossildiagênese, enquanto caracterizações fundamentais para futuras interpretações paleoambientais.

\section{CONSIDERAÇõES FINAIS}

A abundância de filos, somada à preservação de partes moles, posiciona o Intervalo Fossílifero do Folhelho Lontras como um dos mais promissores Lagerstatte do Paleozoico do Gondwana Oeste. Desde a sua descoberta, no século XX, o IFFL desperta o interesse da comunidade científica pela sua biota mista e pelo seu contexto paleodeposicional. Apesar do intervalo métrico do Folhe- lho Lontras, há registros da ocorrência de intervalos semelhantes em outras duas localidades: um, na cidade de Mafra, e outro, em Rio dos Cedros, ambos em Santa Catarina.

Entre as pesquisas realizadas, nos últimos anos, a associação do IFFL tem proporcionado informações importantes para o entendimento da evolução filogenética, como visto em poríferos, em conodontes e em peixes paleoniscídeos. Além disso, a descoberta de casulos larvais trouxe novas hipóteses para a origem e para a ecologia do hábito de produzir casulos na Ordem Trichoptera.

Apesar do progresso realizado no entendimento da biota do IFFL, a partir de trabalhos sistemáticos, realizados por diversos paleontólogos brasileiros, importantes informações tafonômicas e taxonômicas ainda continuam em aberto. Portanto, há de se continuar a estudar e a preservar esse importante Lagerstatte brasileiro.

\section{REFERÊNCIAS}

Adami-Rodrigues, K., Pazinato, P. G., Correa, R. C., Ricetti, J. H. Z. \& Weinschütz, L. C. 2012. Malacostraca da Formação Rio do Sul, Grupo Itararé, Bacia do Paraná, Mafra, SC, Brasil. In: Ghilardi, R. P. \& Scheffler, S. M. (Eds. ). SIMPÓSIO BRASILEIRO DE PALEOINVERTEBRADOS, 1., Bauru, 2012. Boletim de Resumos. Bauru, UNESP.

Allison, P. A., Ford, R. \& Corfield, R. M. 1998. Stratification and oxygen isotopes in the $\mathrm{Pa}$ leozoic: is paleothermometry in hot water? Stable isotopes in geology. Palaeontol. Soc., 4(Spec. Publ. ): 244-254.

Archer, A. W. \& Feldman, H. R. 1990. Tidal rhythmites within the Lawrence Formation (Pennsylvanian, Virgilian) of Kansas. Abstracts, Kansas Academy of Science, 9: 4.

Buggisch, W., Wang, X. D., Alekseev, A. S. \& Joachimski, M. 2011. Permo Carboniferous carbon isotope stratigraphy of sections from China (Yangtze platform), USA (Kansas) and 
Russia (Moscow Basin and Urals). Palaeogeogr. Palaeoclimatol. Palaeoecol., 301: 18-38.

Buso, V., Aquino, C. D., Paim, P. S. G., Souza, P. A., Mori, A. L., Fallgater, C., Milana, J. P. \& Kneller, B. 2019. Late Palaeozoic glacial cycles and subcycles in western Gondwana: Correlation of surface and data of the Paraná Basin, Brazil. Palaeogeogr. Palaeoclimatol. Palaeoecol., 531(Part B): 108435. DOI: https://doi.org/ 10.1016/j.palaeo.2017.09.004.

Cagliari, J., Philipp, R. P., Valdez, B. V., Netto, R. G., Hillebrand, P., Lopes, C. R., Basei, M. A. S. \& Faccini, U. F. 2016. Age constraints of the glaciation in the Paraná Basin: evidence from new U-Pb dates. J. Geol. Soc., 173: 871-874.

Canuto, J. R. 1999. Facies e ambientes de sedimentação da Formação Rio do Sul (Permiano), Bacia do Paraná, na região de Rio do Sul, Estado de Santa Catarina. São Paulo, 184 p. Tese de Doutorado, Universidade de São Paulo.

Cardoso, A. R., Romero, G., Osés, G. L. \& Nogueira, A. C. R. 2020. Taphonomy of lacustrine fish fossils of the Parnaíba Basin, northeastern Brazil: Spatial and causative relations of Konservat Lagerstätten in West Gondwana during Jurassic-Cretaceous. Paleogeography, Palaeoclimatology, Palaeoecology, 542: 21. DOI: https://doi.org/10.1016/j.palaeo.2020.109602

Carvalho, P. F., Miranda, J. \& Alvim, P. A. 1942. Geologia de Mafra. Boletim da Divisão de Geologia e Paleontologia, DNPM, 105: 1-41.

Cunningham, C. R., Feldman, R. H., Frankseen, E. K., Gastaldo, R. A., Mapes, G., Maples, C. G. \& Schutze, H. P. 1993. The Upper Carboniferous Hamilton Fossil-Lagerstatte in Kansas: a valley-fill, tidally influenced deposit. Lethaia, Oslo, 26: 225-236. ISSN 0024-1164.

Dias, M. E. R. 1993. Palinologia do Grupo Itararé no Rio Grande do Sul. Porto Alegre, 227p. Tese de Doutorado, Universidade Federal do Rio Grande do Sul.

Dino, R. \& Rösler, O. 2001. Significado estrati- gráfico e paleoambiental da palinoflora de concreções da Formação Rio do Sul (Neopaleozóico da Bacia do Paraná) na região de Mafra, SC. Revista Brasileira de Paleontologia, 2: 148-149.

Fallgatter, C. \& Paim, P. S. G. 2017. On the origin of the Itarare Group basal nonconformity and its implications for the Late Paleozoic glaciation in the Paraná Basin, Brazil. Palaeogeogr. Palaeoclimatol. Palaeoecol., 531: 108225. DOI: https://doi.org/10.1016/j. palaeo.2017.02.039

Fedorchuk, N. D., Isbell, J. L., Griffis, N. P., Montañez, I. P., Vesely, F. F., Iannuzzi, R., Mundil, R., Yin, Q. Z., Pauls, K. N. \& Rosa, E. L. 2018. Origin of paleovalleys on the Rio Grande do Sul Shield (Brazil): implications for the extent of late Paleozoic glaciation in westcentral Gondwana. Palaeogeogr. Palaeoclimatol. Palaeoecol., 531: 108738.

Fedorchuk, N. D., Isbell, J. L., Griffis, N. P., Vesely, F. F., Rosa, E. L. M., Montãnez, I. P., Mundil, R., Yin, Q. Z., Iannuzzi, R., Roesler, G. \& Pauls, K. N. 2019. Carboniferous glaciotectonized sediments in the southernmost Paraná Basin, Brazil: Ice marginal dynamics and paleoclimate indicators. Sediment. Geol., 389: 54-72.

França, A. B. \& Potter, P. E. 1988. Estratigrafia, ambiente deposicional e análise de reservatório do Grupo Itararé (Permocarbonífero), Bacia do Paraná (Parte 1). Rev. Geoci. Petrobras, 2(2-4): 147-191.

Gnaedinger, S., Kloster, A. C., Adami-Rodrigues, K., Urban, C. \& Scomazzon, A. K. 2012. Permineralized Woods from Upper Carboniferous - Lower Permian of the Itararé Group, Brazil. In: ENCONTRO PAN-AMERICANO DA IAWA, Recife. Anais... Recife, p. 58-59.

Griffis, N. P., Mundil, R., Montañez, I. P., Isbell, J., Fedorchuk, N., Vesely, F., Iannuzzi, R. \& Yin, Q. Z. 2018. A new stratigraphic framework built on U-Pb single-zircon TIMS ages and implications for the timing of the penultimate icehouse (Paraná Basin, Brazil). GSA Bull., 130(5-6): 848-858. 
Griffis, N. P., Montañez, I. P., Fedorchuk, N., Isbell, J., Mundil, R., Vesely, F., Weinshultz, L., Iannuzzi, R., Gulbranson, E., Taboada, A., Pagani, A., Sanborn, M. E., Huyskens, M., Wimpenny, J., Linol, B. \& Yin, Q. Z. 2019a. Isotopes to ice: constraining provenance of glacial deposits and ice centers in west-central Gondwana. Palaeogeography, Palaeoclimatology, Palaeoecology, 531 (Part B): 108745. DOI: https://doi.org/10.1016/J.PALAEO. 2018.04.020.

Hamel, M. H. 2005. A new actinopterygian from the Early Permian of the Paraná Basin, Brazil. J. Vertebr. Paleontol., 25(1): 19-26.

Holz, M., França, A. B., Souza, P. A., Ianuzzi, R. \& Rohn, R. 2010. A stratigraphic chart of the Late Carboniferous/Permian succession of the eastern border of the Paraná Basin, Brazil, South America. J. S. Am. Earth Sci., 29: 381-399.

Iannuzzi, R., Weinschütz, L. C., Adami-Rodrigues, K., Lemos, V. B., Ricetti, J. H. Z. \& Wilner, E. 2014. The Campáleo Lontras Shale outcrop: a potencial stratotype for the Carboniferous-Permian transition in the Paraná Basin. In: CPC-2014 FIELD MEETING ON CARBONIFEROUS AND PERMIAN NONMARINE - MARINE CORRELATION, Technische Universitat Bergakademie Freiberg, 2014. Abstract volume, p. 24.

Isbell, J. L., Henry, L. C., Gulbranson, E. L., Limarino, C. O., Fraiser, M. L., Koch, Z. J., Ciccioli, P. L. \& Dineen, A. A. 2012. Glacial paradoxes during the late Paleozoic ice age: evaluating the equilibrium line altitude as a control on glaciation. Gondwana Res., 22: 1-19.

Kallen, C. V. D., Scomazzon, A. K., Urban, C. \& Adami-Rodrigues, K. 2014. Novo registro de ostracodes do grupo Itararé, Formação Taciba, Membro Rio do Sul, Mafra, Santa Catarina. In: 23ํ CONGRESSO DE INICIAÇÃO CIENTÍFICA DA UNIVERSIDADE FEDERAL DE PELOTAS. Anais. . . Pelotas, p. 32.

Koester, E., Scomazzon, A. K., Weinschütz, L. C., Wilner, E., Moutinho, L. P. \& Nascimento, S. 2016. Idade Rb-Sr do Folhelho Lontras, Gru- po Itararé, Bacia do Paraná, na Região de Mafra, SC, Brasil. In: $48^{\circ}$ CONGRESSO BRASILEIRO DE GEOLOGIA. Anais. . . p. 955.

Kuecher, G. J., Woodland, B. G. \& Broadhurst, F. M. 1990. Evidence of deposition from individual tidal cycles from the. Francis Creek Shale (host rock to the Mazon Creek Biota), Westphalian D (Pennsylvanian), northeastern Illinois. Sedimentary Geology, 68: 211221.

Lavina, E. L. C. \& Lopes, R. C. 1987. A transgressão Marinha do Permiano Inferior e a Evolução Paleogeográfica do Supergrupo Tubarão no estado do Rio Grande do Sul. Paula-Coutiana, 1: 51-103.

Lopes, T. K. 2016. Análise bioestratigráfica e paleoambiental do Folhelho Lontras, Topo da Formação Campo Mourão, Grupo Itararé, no Afloramento Campáleo, na cidade de Mafra, $S C$. Florianópolis, 95p. Monografia, Universidade do Contestado.

Lopes, R. D. C., Lavina, E. L. C. \& Signoreli, N. 1986. Fácies sedimentares e Evolução Paleoambiental do Supergrupo Tubarão na Borda Leste da Bacia do Paraná: uma seção regional nos estados do Rio Grande do Sul e Santa Catarina. In: BRAZILIAN GEOLOGICAL CONGRESS, 24., Goiânia. Anais... Goiânia, SBG, v. 1, p. 206-208.

Machado, M. A. P. 1994. O Degelo final permiano e o seu registro geológico na borda sudeste da Bacia do Paraná (Paleovale de Candiota-RS). Porto Alegre, 165p. Dissertação de Mestrado, Universidade Federal do Rio Grande do Sul.

Malabarba, M. C. S. L. 1988. A new genus and species of stem group actinopteran fish from the Lower Permian of Santa Catarina State, Brazil. Zool. J. Linnean Soc., 94: 287-299.

Martins-Neto, R. G. 2005. Estágio atual da paleoartropodologia brasileira: hexápodes, miriápodes, crustáceos (Isopoda, Decapoda, Eucrustacea e Copepoda) e quelicerados. $A r-$ quivos do Museu Nacional, 63(3): 471-494. 
Montañez, I. P. \& Poulsen, C. J. 2013. The Late Paleozoic ice age: an evolving paradigm. In: Jeanloz, R. (Ed. ). Annual Review of Earth and Planetary Sciences, 41: 629.

Mouro, L. D. 2013. Poríferos do Afloramento Campáleo (Cisuraliano), Folhelho Lontras, Mafra, SC. Rio de Janeiro, 94p. Dissertação de Mestrado, Universidade Federal do Rio de Janeiro.

Mouro, L. D. 2017. Paleoecologia do Folhelho Lontras, Formação Campo Mourão, Cisulariano, Brasil. Rio de Janeiro, 213p. Tese de Doutorado, Programa de Pós-graduação em Geologia, Universidade Federal do Rio de Janeiro.

Mouro, L. D., Fernandes, A. C. S., Rogério, D. W. \& Fonseca, V. M. M. 2014a. First articulated sponge from the Paleozoic of Brazil, and a new organization of the Order Hemidiscosa. J. Paleontol., 88(1): 171-178.

Mouro, L. D., Fernandes, A. C. S., Zaton, M., Flach, M. K. \& Mouro Junior, J. C. 2014b. Marine Caddisflies larval cases from the Permian of Brazil. In: 4TH INTERNATIONAL PALEONTOLOGICAL CONGRESS, Mendonza. Abstracts. Mendoza, p. 759.

Mouro, L. D., Zaton, M., Fernandes, A. C. S. \& Waichel, B. L. 2016. Larval cases of caddisfly (Insecta: Trichoptera) affinity in Early Permian marine environments of Gondwana. Nature Scientific Reports, 6: 1-7. Disponível em: www. nature. com/scientificreports/. Acesso em: 14 jan. 2016. DOI: https://doi. org/10.1038/srep19215

Mouro, L. D., Rakocinski, M., Marynowski, L., Pisarzowska, A., Musabelliu, S., Zaton, M., Carvalho, M. A., Fernandes, A. C. S. \& Waichel, B. L. 2017. Benthic anoxia, intermittent photic zone euxinia and elevated productivity during deposition of the Lower Permian, post-glacial fossiliferous black shales of the Paraná Basin, Brazil. Glob. Planet. Chang., 158: 155-172.

Mouro, L. D., Fernandes, A. C. S., Carvalho, M. A. \& Weinschutz, L. C. 2018. O Folhelho Lon- tras (Permiano, Bacia do Paraná) e seus Fósseis: Descoberta, Identificação e Conhecimento Atual. Anuário do Instituto de Geociências, 41(2): 636-646.

Mouro, L. D., Pacheco, M. L. A. F., Ricetti, J. H. Z., Scomazzon, A. K., Horodyski, R. S., Fernandes, A. C. S., Carvalho, M. A., Weinschütz, L. C., Silva, M. S., Waichel, B. L. \& Scherer, C. M. S. 2020. Lontras Shale (Paraná Basin, Brazil): Insightful analysis and commentaries on paleoenvironment and fossil preservation into a deglaciation pulse of the Late Paleozoic Ice Age. Palaeogeography, Palaeoclimatology, Palaeoecology, 555: 109850.

Muller, C., Mouro, L. D., Silva, M. S. \& Vieira, L. D. 2017. Coprolites of Campaleo outcrop, Lontras Shale, Campo Mourão Formation, in Mafra-SC. In: XXV CONGRESSO BRASILEIRO DE PALEONTOLOGIA, 1, Ribeirão Preto. Boletim de Resumos. Ribeirão Preto, p. 211.

Neves, J. P., Taboada, A. C., Weinschütz, L. C. \& Simões, M. G. 2017. Brachiopods of the Itararé Group from Mafra County, Southern Brazil, and their geological significance. In: Langer, M. A., Al Halabi, W. A., Ferreira, G. S., Hermanson, G., Marsola, J. C. A. \& Onary-Alves, S. Y. (Eds. ). Paleontologia em Destaque, ano 32 (Edição Especial): 222.

Oliveira, E. P. 1927. Geologia e recursos minerais do Estado do Paraná. Rio de Janeiro, 127p. Monografia, Serviço de Geologia e Mineralogia.

Oliveira, E. P. 1930. Fósseis marinhos na Série Itararé no Estado de Santa Catharina. An. Acad. Bras. Cienc., Rio de Janeiro, 2(1): 17-21.

Osés, G. L., Petri, S., Becker-Kerber, B., Romero, G. R., Rizzutto, M. A., Rodrigues, F., Galante, D., da Silva, T. F., Curado, J. F., Rangel, E. C., Ribeiro, R. P. \& Pacheco, M. L. A. F. 2016. Deciphering the preservation of fossil insects: a case study from the Crato Member, Early Cretaceous of Brazil. PeerJ, 4: e2756. DOI: https:// doi. org/10. 7717/peerj. 2756

Osés, G. L., Petri, S., Voltani, C. G., Prado, G. M. E. M., Galante, D., Rizzutto, M. A., Rudnitzki, I. 
D., da Silva, E. P., Rodrigues, F., Rangel, E. C., Sucerquia, P. A. \& Pacheco, M. L. A. F. 2017. Deciphering pyritization-kerogenization gradient for fish soft-tissue preservation. Sci. Rep., 7: 1468. DOI: https://doi. org/10.1038/ s41598-017-01563-0

Pauliv, V. E., Dias, E. V., Sedor, F. A. \& Weinschütz, L. C. 2014. Elasmobranchii teeth from the Late Carboniferous-Early Permian Itarare Group (Paraná Basin), Southern Brazil. In: SOCIETY OF VERTEBRATE PALEONTOLOGY 74TH ANNUAL MEETING, Berlin. Anais... Berlim, p. 202.

Petri, S. \& Souza, P. A. 1993. Síntese dos conhecimentos e novas concepções sobre a bioestratigrafia do Subgrupo Itararé, Bacia do Paraná, Brasil. Rev. Inst. Geol., 14(2): 7-18.

Pigao, S. G. \& Mouro, L. D. 2019. Identifying microfossils from Lontras shale horizon using petrographic thin-section. In: XI SIMPÓSIO SUL-BRASILEIRO DE GEOLOGIA, Bento Gonçalves. Anais. . Bento Gonçalves, v. 1, p. 235.

Pinto, I. D. \& Sedor, F. A. 2000. A new Upper Carboniferous Blattoid from Mafra Formation Itararé Group, Paraná Basin, Brazil. Pesquisa em Geociências, 27: 45-48.

Ricetti, J. H. Z. \& Weinschütz, L. C. 2011. Ocorrência de escolecodontes (Annelida, Labidognatha) nas formações Mafra e Rio do Sul, Permo-Carbonífero da Bacia do Paraná, Brasil. In: REUNIÃO REGIONAL DE PALEONTOLOGIA DOS ESTADOS DO PARANÁ E SANTA CATARINA - PALEO, 12., Cascavel, 2010. Paleontologia em Destaque, 64: 31-32.

Ricetti, J. H. Z., Wilner, E. \& Weinschütz, L. C. 2014. Novos escolecodontes do contato Carbonífero-Permiano (Grupo Itararé) da Bacia do Paraná na cidade de Mafra, Santa Catarina. In: XVI ENCONTRO REGIONAL DE PALEONTOLOGIA DOS ESTADOS DO PARANÁ E SANTA CATARINA - PALEO, 2014, Florianópolis. Paleontologia em Destaque, 68: 76-77.

Ricetti, J. H. Z., Schneider, J. W., Iannuzzi, R. \& Weinschütz, L. C. 2016. Anthracoblattina mendesi Pinto et Sedor (Blattodea, Phyloblattidae): the most completely preserved South American Palaeozoic cockroach. Rev. Brasil. Paleontol., 19: 181-194.

Richter, M. 1991. A New Marine Ichthyofauna from the Permian of the Paraná Basin of Southern Brazil. Londres, 233p. Tese de Doutorado, King's College London, University of London.

Rösler, O. 1985. Sobre algumas contribuições e paleontologia do Paleozóico Superior do Brasil. Late Paleozoic of South America. In: ANNUAL MEETING OF THE WORKING GROUP, Bogotá. Abstracts. Bogotá.

Ruedemann, R. 1929. Fossils from the Permian Tillite of São Paulo, Brazil, and their bearing on the origin of tillite. Bulletin of the Geological Society of America, 40(2): 417426.

Santos, P. R., Rocha-Campos, A. C. \& Canuto, J. R. 1996. Patterns of Late Palaeozoic deglaciation in the Paraná Basin, Brazil. Palaeogeogr. Palaeoclimatol. Palaeoecol., 125: 165-184.

Seilacher, A. 1970. Begriff Und bedeuntung der Fossil-Lagertätten. In: Neues Jahbuch für geologie und Palãontologie, 1: 34-39.

Selden, P. \& Nudds, J. 2004. Evolution of Fossil Ecosystems. Londres, Manson Publishing, 160p. ISBN 184076040 0; 1840760419

Schneider, R. L., Muhlmann, H., Tommazi, E., Medeiros, R. A., Daemon, R. F. \& Nogueira, A. A. 1974. Revisão estratigráfica da Bacia do Paraná. In: CONGRESSO BRASILEIRO DE GEOLOGIA, 28., Porto Alegre, 1974. Anais. . . Porto Alegre, SBG, 1, p. 41-66.

Scomazzon, A. K., Wilner, E., Purnell, M. A., Nascimento, S., Weinschütz, L. C., Lemos, V. B., de Souza, F. L. \& da Silva, C. P. 2013. First report of conodont apparatuses from Brazil - Permian of Paraná Basin, Itararé Group, Lontras Shale - Evidence of Gondwana deglaciation. In: CONODONT FROM THE ANDES. 3RD INTERNATIONAL CONODONT 
SYMPOSIUM. Paleontological Note, (Publicación Especial 13): 99-102.

Scotese, C. R. 1997. Continental Drift. 7. ed. Arlington, PALEOMAP Project, 79p.

Silveira, A. S. 2000. Estratigrafia de Seqüências e Evolução Paleoambiental da Sucessão Permiana (Sakmariano - Eokazaniano) da Bacia do Paraná, entre Rio Pardo e Mariana Pimentel (RS). São Leopoldo, 140p. Dissertação de Mestrado, Univ. do Vale do Rio dos Sinos.

Souza, P. A. 2005. Late Carboniferous palynostratigraphy of the Itararé Subgroup northeastern Paraná Basin, Brazil. Rev. Palaeobot. Palynol., 138: 9-29.

Tedesco, J., Cagliari, J., Coitinho, J. R., Lopes, R. C. \& Lavina, E. L. C. 2016. Late Paleozoic paleofjord in the southernmost Parana Basin (Brazil): geomorphology and sedimentary fill. Geomorphology, 269: 203-214.

Urban, C., Gnaedinger, S., Rodrigues, K. A. \& Scomazzon, A. K. 2012. Primer Registro de maderas fósiles del Grupo Itararé, Carbonífero Superior-Pérmico Inferior, Brasil. In: II SIMPÓSIO ARGENTINO DE MELISOPALINOLOGIA, Buenos Aires. Anais... Buenos Aires, p. 126.

Vesely, F. F., Trzaskos, B., Kipper, F., Assine, M. L. \& Souza, P. A. 2015. Sedimentary record of a fluctuating ice margin from the Pennsylvanian of western Gondwana: Paraná Basin, southern Brazil. Sediment. Geol., 326: 45-63.

Weinschütz, L. C. 2010. Divisão do Afloramento Campáleo. In: I CONODONT MEETING, Mafra. Anais... Mafra, p. 1-3.

Weinschütz, L. C. \& Castro, J. 2005. A Sequência Mafra Superior/Rio do Sul Inferior (Grupo Itararé, Permocarbonífero) em sondagens testemunhadas da região de Mafra, SC, margem leste da Bacia do Paraná. Geociências, 24: 131-141.

Weinschütz, L. C. \& Castro, J. C. D. 2004 Arcabouço cronoestratigráfico da Formação Ma- fra (intervalo médio) na região de Rio Negro/ PR-Mafra/SC, borda leste da Bacia do Paraná. Rem: Revista Escola de Minas, 57(3): 151156.

Weinschütz, L. C., Neves, J. P., Hadler, P., Ricetti, J. H. Z. \& Wilner, E. 2018. Ocorrência inédita de Ammonoidea (Mollusca: Cephalopoda), no Permiano da Bacia do Paraná. In: PALEO PR/SC, 2018, Curitiba. Livro de resumos paleo pr/sc 2018. Curitiba, v. 1.

Weinschütz, L. C., Pscheidt, C., Strapasson, E. V. L., Hirth, C., Wantowsky, M. D., Ricetti, J. H. Z. \& Wilner, E. 2019. A importância de museus no interior-o caso CENPALEO/MTV. Revista Baru-Revista Brasileira de Assuntos Regionais e Urbanos, 5(1): 68-83.

Wells, M. R., Allison, P. A., Hampson, G. J., Piggott, M. D. \& Pain, C. C. 2005. Modelling ancient tides: the Upper Carboniferous epi-continental seaway of Northwest Europe. Sedimentology, 52: 715-735.

Wilner, E., Lemos, V. B. \& Scomazon, A. K. 2016a. Associações naturais de conodontes Mesogondolella spp., Grupo Itararé, Cisuraliano da Bacia do Paraná. GAEA J. Geosci., 9(1): 30-36.

Woodworth, J. B. 1912. Geological expedition to Brazil and Chile, 1908-1909. Bull. Museum Compar. Zool., 56(1): 3-137.

Zidek, J. 1992. Geology and paleontology of the Kinney Brick Quarry, Late Pennsylvanian, central New Mexico. In: Zidek, J. (Ed. ). New Mexico Bureau of Mines and Mineral Resources Bulletin, 138: 1-242.

Ziegler, A. M., Hulver, M. L. \& Rowley, D. B. 1997. Permian world topography and climate. In: Martini, I. P. (Ed. ). Late Glacial and Postglacial Environmental Changes: Quaternary, Carboniferous-Permian and Proterozoic. Oxford, Oxford University Press, p. 111-146. 



\title{
Ocorrência de Conodontes - vertebrados primitivos - na Supersequência Gondwana I, Grupo Itararé, folhelho Lontras - Afloramento Campaleo (SC), Cisuraliano, Bacia do Paraná
}

\author{
Ana Karina Scomazzon ${ }^{1 *}$, Everton Wilner,2, Luiz Carlos Weinschütz ${ }^{2}$, \\ Sara Nascimento ${ }^{1}$, Valesca Brasil Lemos $^{1}$ \\ ${ }^{1}$ Instituto de Geociências, Universidade Federal do Rio Grande do Sul \\ ${ }^{2}$ Centro Paleontológico da Universidade do Contestado (CENPALEO), Universidade do Contestado
}

*autor correspondente: akscomazzon@ufrgs.br

\section{INTRODUÇão}

Conodontes são vertebrados primitivos, encontrados nos estratos marinhos do Cambriano ao Triássico, nas bacias sedimentares mundiais. São potencialmente úteis, para a bioestratigrafia, sendo ótimos fósseis-guia, durante os 300 milhões de anos de sua existência. São importantes indicadores geotermais, através do Índice de Alteração de Cor (IAC), pois seus elementos podem variar de cor entre amarelo pálido e preto $\left(50^{\circ} \mathrm{C}\right.$ a $\left.600^{\circ} \mathrm{C}\right)$, constituindo-se em ferramenta estratégica na pesquisa de hidrocarbonetos, nas bacias sedimentares paleozoicas mundiais (Epstein et al., 1977).

Através do avanço em equipamentos de tomografia computadorizada, em espectrômetros de massa, em aceleradores de partículas, entre outros, tem sido possível utilizar estes fósseis em estudos de paleotemperaturas, de quimioestratigrafia, de correlação de bacias, de cronoestratigrafia, de bioestratigrafia, de paleoecologia, de reconstituições paleoambientais e paleobiogeográficas, de tafonomia, de entendimento da origem dos vertebrados, de exploração de hidrocarbonetos, entre outros.

No registro sedimentar, é possível encontrar os conodontes de três formas distintas: (1) o animal conodonte (Fig. 1), vertebrado primitivo, cujo corpo era composto de material orgânico, que se decompunha facilmente, com preservação fossilífera extremamente rara; (2) os aparelhos alimentares, formados por conjuntos de elementos conodontes; e (3) os chamados elementos conodontes, única porção mineralizada do organismo, os quais possuem diferentes morfologias e formam arranjos em posições específicas nos aparelhos alimentares, na região cefálica do animal (Fig. 2). 


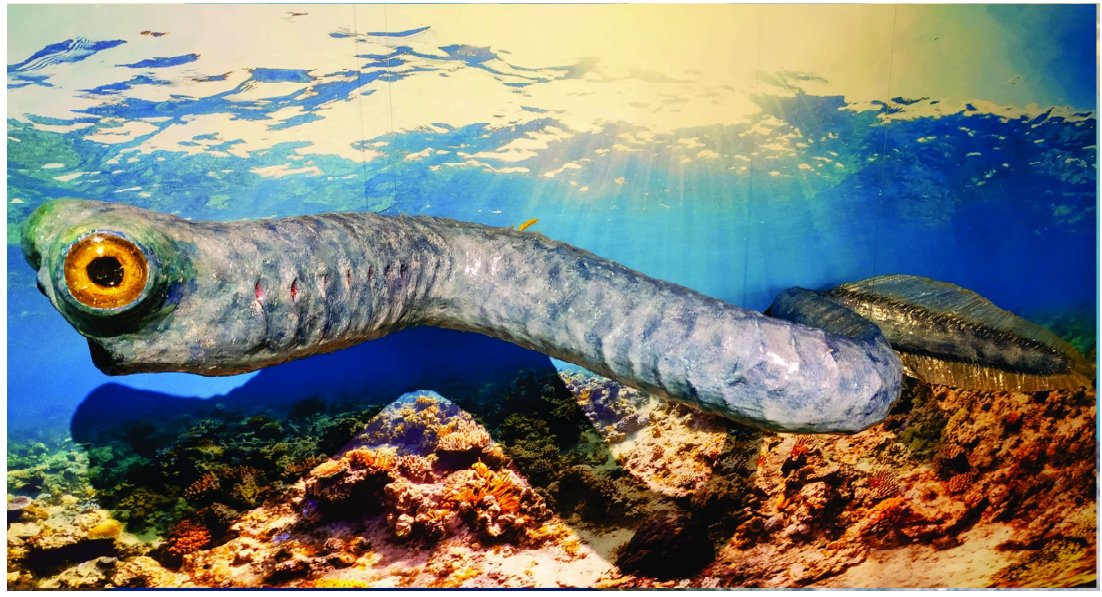

Figura 1 - Escultura do animal conodonte em escala de 1:25, exposta no Museu da Terra e da Vida, do Centro Paleontológico da Universidade do Contestado, campus Mafra (SC), com 1,20 m de comprimento (acervo de imagens de Everton Wilner).

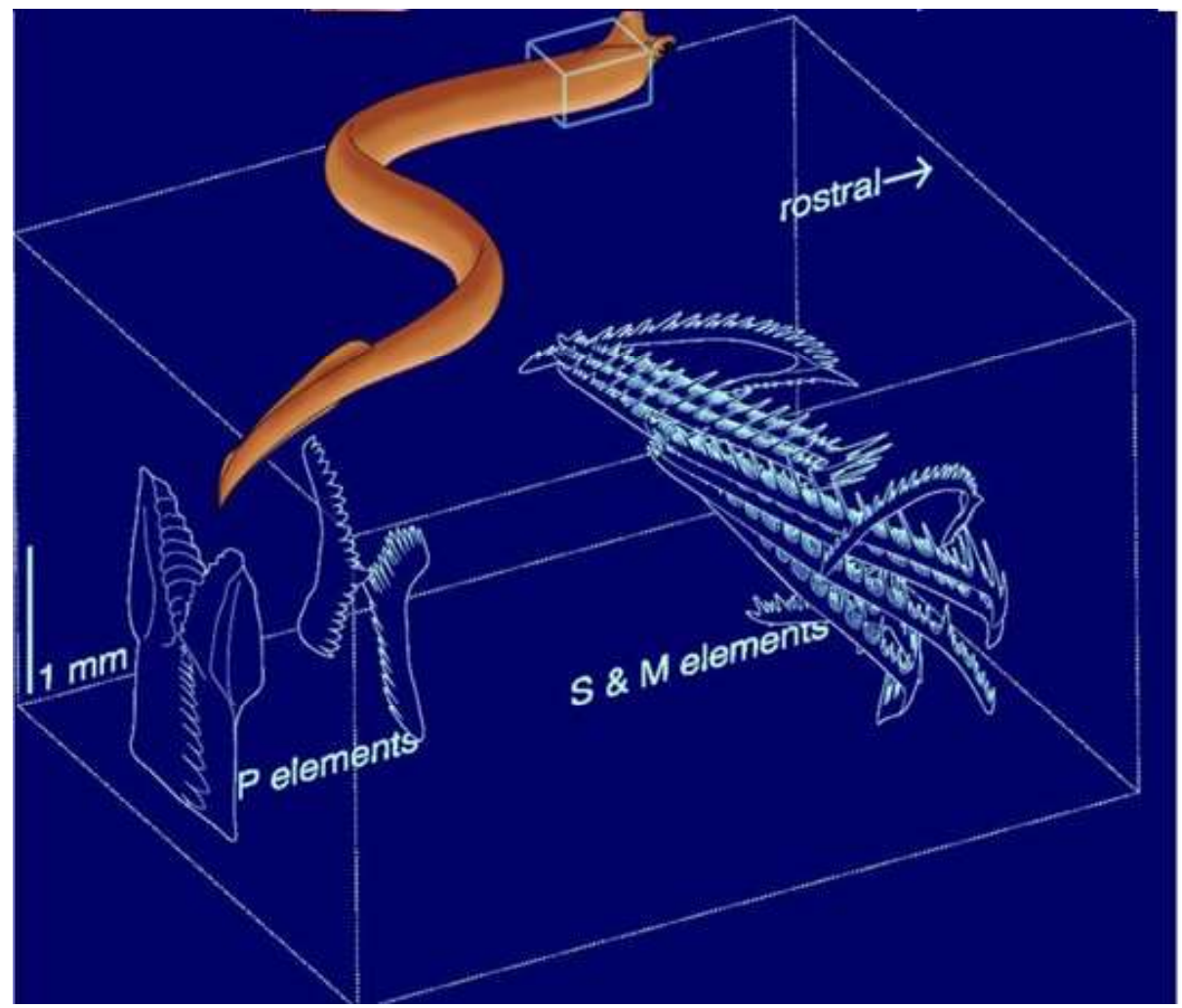

Figura 2 -Animal conodonte. Detalhe da organização do aparelho alimentar, na região cefálica do animal, com os elementos pectiniformes (P) e ramiformes (S e M), (extraído de Purnell, 1993).

Na composição deste conjunto: animal conodonte, aparelhos alimentares e elementos conodontes, estes últimos foram os primeiros a serem encontrados, sendo descritos, pela primeira vez, por Christian Heinrich Pander, em 1856, ao estudar estratos ordovicianos da Estônia. Foram assim deno- minados, devido a sua morfologia cônica (do grego kônos = cone e odontos = dentes). Pander foi um dos fundadores da Embriologia e da Paleontologia na Rússia e considerou estes elementos mineralizados isoladamente, a partir dos quais derivou o conceito de conodonte, designando dentes e/ou mandíbulas

224 Edição da Sociedade Brasileira de Geologia - Núcleo RS/SC 
de um grupo desconhecido de peixes fósseis.

Os elementos, que são microscópicos, medindo 0,25-2 mm, compostos de fosfato de cálcio (fluorapatita > francolita), formam um aparelho alimentar, localizado na porção anterior do animal.

0 aparelho alimentar completo compreende 15 ou mais elementos e sua função, como peças bucais mastigatórias, foi estabelecida, na década de 1990 (Purnell, 1993). Em circunstâncias favoráveis, em que não tenha ocorrido atividade de correntes, de escavadores ou de bioturbação, os aparelhos alimentares, menos comumente, ou os elementos conodontes, diversos e abundantes, podem ser preservados intactos em camadas de rochas sedimentares, principalmente, em folhelhos e em carbonatos. Porém, evidências das partes moles, como o tecido mineralizado fossilizado do animal conodonte, são extremamente raras (Briggs et al., 1983; Aldridge et al., 1993).

No Brasil, o clado é representado por elementos conodontes ozarkodinídeos e prioniodinídeos, encontrados como restos e, por vezes, como moldes, estudados em poços e em afloramentos de depósitos marinhos epeiricos carboníferos, de águas rasas e quentes da região norte, nas bacias sedimentares do Solimões, do Amazonas, do Parnaíba, e, no Permiano, na Bacia do Acre. Muitos trabalhos foram publicados pelo grupo de pesquisa do Laboratório de Conodontes da UFRGS, desde a década de 1990, até hoje, tais como artigos, resumos em eventos, mestrados e doutorados, dentre eles, Lemos (1992a, 1992b), Lemos \& Silva (1996), Lemos \& Scomazzon (2001), Nascimento et al. (2010), Scomazzon et al. (2016).

Na Bacia do Paraná, elementos conodontes prioniodinídeos do gênero Mesogondolella spp. são encontrados no folhelho fossilífero Lontras, relacionado a depósitos marinhos siliciclásticos, de águas frias, asso- ciados à deglaciação do Gondwana, no final do Carbonífero, início do Permiano. Por constituírem um dos achados mais completos no mundo, dada a sua excepcional preservação, esses fósseis, preservados em arranjos naturais, auxiliam nos estudos tafonômicos, no entendimento dos posicionamentos paleogeográfico, paleoclimático e paleoambiental do Gondwana e, também, no posicionamento bioestratigráfico da sucessão sedimentar Supersequência Gondwana I, na qual esses fósseis estão inseridos (Scomazzon et al., 2013, Wilner et al., 2016, Henderson, 2018).

\section{Posição FILOGENÉTICA}

A afinidade filogenética dos conodontes é uma das temáticas mais discutidas entre os paleontólogos. Tais organismos já foram considerados como pertencentes aos filos Cnidária, Braquiopoda, Annellida, Mollusca, Arthropoda, bem como pertenceram a plantas (Müller, 1981, p. W79). Foram também considerados como filo Chaetognatha (Bengtson, 1983), como filo Conodonta (Briggs et al., 1983; Sweet, 1988) e, ainda, como filo Chordata (Dzik, 1986; Aldridge et al., 1986, 1993; Briggs et al., 1987; Janvier, 1995).

Pander já acreditava que os elementos conodontes fossem partes duras, porções mineralizadas (dentes ou a mandíbula) de um grupo extinto de peixes. Entretanto, outros pesquisadores, como Newberry (1875 apud Sweet, 1988) e Hinde (1879 apud Aldridge et al., 1987), eram mais favoráveis à ideia de que tais elementos seriam semelhantes aos dentes dos mixinóides, como a Myxina, devido ao brilho e à forma semelhantes, apesar de saberem que, internamente, ambos, Myxina e conodontes, tinham estruturas completamente diferentes, além de os conodontes serem fosfáticos e as estruturas dos peixe-bruxa, orgânicas. 
Ulrich \& Bassler (1926 apud Sweet, 1988) também aceitavam a ideia de que os conodontes fossem dentes ou placas dermais de peixes primitivos, semelhantes aos mixinóides. Gross (1954 apud Sweet, 1988), estudando a estrutura lamelar dos elementos conodontes, concluiu que estes, de fato, eram representantes dos Cordados, porém de um ramo distinto do dos Agnatha.

Com a descoberta do primeiro espécimen do animal conodonte no Granton Shrimp Bed, na Escócia (Briggs et al., 1983), estes autores postularam que os conodontes não seriam pertencentes nem ao filo Chaetognatha, nem aos Cordados, devido à falta de dentina ou de qualquer outra evidência, no fóssil, que comprovasse seu posicionamento em um ou em outro filo. Assim, Briggs et al. (1983) concluíram que os conodontes pertenciam a um filo separado, denominado filo Conodonta. Mais tarde, foram descobertos outros espécimes, com melhor preservação, naquele mesmo local, cujas feições das partes orgânicas indicaram, claramente, uma afinidade com os Agnatha (Aldridge et al., 1986; Dzik, 1986; Conway-Morris, 1989; Briggs, 1992).

Utilizando microscópio eletrônico de varredura e de transmissão, Szaniawski (1987) estudou a microestrutura e a composição do corpo basal de alguns elementos conodontes. Fazendo comparações entre os conodontes e os Chaetognatha, Szaniawski (1987) concluiu que, provavelmente, os conodontes não seriam Chaetognatha sensu stricto, mas que ambos teriam se originado de um ancestral comum.

Com os novos espécimens do Granton Shrimp Bed, Aldridge et al. (1993) consideraram os conodontes representantes de um grupo paralelo aos Agnatha, porém com semelhanças próximas aos mixinóides, não tendo mais propósito colocá-los como um filo separado. Estes espécimens mostraram que os conodontes eram animais pequenos, com aproximadamente 4 centímetros, com forma de enguia, com olhos proporcionalmente grandes, com notocorda, com miômeros (blocos de músculos em forma de $\mathrm{V}$ ) nas laterais do corpo e com nadadeira caudal. Essas características inserem os conodontes no filo Chordata (Purnell et al., 1995). Além disso, foram identificados, em alguns conodontes: tecido ósseo, esmalte, cartilagem calcificada e dentina, que são características únicas dos vertebrados (Sansom et al., 1992, 1994).

As evidências da anatomia das partes moles e a microestrutura dos elementos conodontes indicam que esses animais estão entre os vertebrados mais primitivos. Contudo, a falta de um esqueleto mineralizado (a não ser o aparelho alimentar, que é fosfático) leva a crer que eles seriam mais primitivos do que os Agnatha (e.g. Ostracodermos = astraspídeos, pituriaspídeos, etc. ), mas mais avançados do que os mixinóides (e.g. Myxina, que não possuem esqueleto fosfático no aparelho alimentar), sugerindo que os conodontes seriam os vertebrados mais primitivos, encontrados até hoje (Purnell et al., 1995).

Apesar destas descobertas e dos trabalhos baseados na histologia dos elementos (Sansom et al., 1994), que revelaram várias características dos vertebrados, alguns especialistas em vertebrados primitivos têm, ainda, dúvidas, com relação à afinidade dos conodontes, por acreditarem que tais características não são suficientes para considerá-los vertebrados (Blieck, 1992; Forey \& Janvier, 1993; Janvier, 1988, 1996).

\section{ANIMAL CONODONTE}

0 primeiro registro de tecido fossilizado de conodontes foi de um único espécimen do Carbonífero da Escócia (Granton Shrimp Bed), sendo o horizonte fossilífero 
composto por dolomitos marrons, pobres em matéria orgânica, e por laminações de silte preto, ricos em matéria orgânica, em fácies proximais, de água rasa. 0 registro fossilífero continha o aparelho alimentar completo na região cefálica (Briggs et al., 1983). Posteriormente, foram encontrados mais três espécimens neste mesmo horizonte fossilífero, que trouxeram maiores informações, com respeito às partes orgânicas, apesar destes serem menos completos do que o primeiro animal encontrado (Aldridge et al., 1986). Seis novos espécimes foram coletados no Granton Shrimp Bed da Escócia, perfazendo um total de 10 espécimes, atualmente. Alguns deles, com feições particularmente bem preservadas da cabeça e do tronco, corroborando as primeiras interpretações.

Um único exemplar de um conodonte panderodontídeo, pouco preservado, foi encontrado no Siluriano, em Waukesha, Wisconsin (Smith et al., 1987) e traços de partes orgânicas foram encontradas, em associação com aparelhos alimentares gigantes (em torno de $20 \mathrm{~mm}$ ) de conodontes, no Ordoviciano Superior da África do Sul (Aldridge \& Theron, 1993). Os espécimens de Waukesha e da África do Sul revelaram detalhes sobre estruturas na cabeça e sobre possíveis traços do tronco do animal. Porém, os espécimens de Granton provêm as evidências mais completas, a respeito da anatomia dos conodontes.

Os conodontes do Granton Shrimp Bed, Carbonífero da Escócia, eram animais pequenos, com comprimento entre $21 \mathrm{~mm}$ e $55 \mathrm{~mm}$, largura entre $1,2 \mathrm{~mm}$ e $1,8 \mathrm{~mm}$, lateralmente comprimidos e dominantemente formados por um corpo orgânico. Eram semelhantes a enguias e, provavelmente, deviam ser predadores livre natantes.

Na região anterior do corpo do animal, observa-se a cabeça, que é pequena e que acomoda o aparelho alimentar, seguida por um tronco com músculos em $\mathrm{V}$ e, na região posterior, encontra-se uma nadadeira caudal radiada (Aldridge et al., 1993).

Na margem anterior da cabeça, existem duas estruturas lobadas, de cor mais escura do que as estruturas mineralizadas do tronco. Inicialmente, esses lobos foram considerados, por Aldridge \& Theron (1993), como "cápsulas ópticas", mas essa hipótese foi logo descartada, devido ao tamanho, à forma e à posição dos lobos. Comparações com outros fósseis Agnatha, incluindo Jamoytius, um anaspídeo do Siluriano, sugeriram que os lobos representavam cartilagens escleróticas, que ocorriam ao redor dos olhos. No animal do Granton Shrimp Bed, essa cartilagem parece ser profunda, com buracos internos, em forma de anel, indicando que os olhos eram relativamente grandes e lateralmente posicionados (Briggs et al., 1983). A presença de olhos grandes nesses espécimes sugere um aparelho cefálico mais avançado do que o dos cefalocordados (e.g. Amphioxus) (Purnell, 1995).

Traços adicionais de partes orgânicas na região da cabeça foram, em princípio, relacionadas aos olhos (Aldridge \& Briggs, 1989), mas, atualmente, são consideradas cápsulas ópticas, assim como alguns traços transversais pálidos, que são interpretados como estruturas branquiais (Aldridge et al., 1993).

A maioria dos elementos do aparelho alimentar dos conodontes do Granton Shrimp Bed é de ozarkodinídeos. Consistem em 11 elementos ramiformes $\mathrm{M}$ e $\mathrm{S}$, formando uma espécie de cesta, que tinha a função de capturar a presa. Posterior a estes, existem dois pares sucessivos de elementos pectiniformes P1 e P2, que eram utilizados para processar o alimento (Jeppsson, 1979; Briggs et al., 1983; Purnell \& von Bitter, 1992). 0 aparelho dos ozarkodinídeos pode ser preservado em várias configurações, dependendo de sua orientação no plano do 
acamadamento (Aldridge et al., 1987). 0 aparelho dos espécimens do Granton Shrimp Bed são achatados lateralmente, correspondendo à orientação standard, de Aldridge et al. (1987).

As principais feições encontradas no tronco do animal são notocorda, miômeros e nadadeira caudal radiada. A notocorda é evidenciada por um par de linhas axiais paralelas, que se estendem, anteriormente, até próximo do aparelho alimentar, e, posteriormente, até a ponta da cauda. A posição da notocorda pode variar, ao longo do comprimento do animal, porém, geralmente, ocorre mais ou menos ao longo do eixo mediano da cauda e pode estar deslocada para a posição ventral no comprimento do tronco (Aldridge et al., 1993). Esta estrutura foi sujeita a uma série de interpretações anteriores (Aldridge et al., 1986), porém novas evidências indicaram que ela realmente representa a notocorda, como sugerido por Conway-Morris (1989).

Os miômeros dos espécimes do Granton Shrimp Bed são uma das peças mais importantes na discussão da afinidade destes animais aos Cordados. Em todos os espécimes, podem-se observar estas estruturas, que consistem em um arranjo de miômeros lateralmente pareados e com forma chevron. A posição desses músculos varia, em relação à notocorda, ao longo do tronco do animal. Segundo Aldridge et al. (1993), tais músculos poderiam ser uma adaptação para escavar o sedimento.

A nadadeira caudal é observada em alguns espécimens, mas não está bem preservada, sendo difícil definir se ela seria simétrica ou se ela se estenderia levemente mais para a região ventral ou dorsal. Em um dos espécimens, os raios da nadadeira são claramente evidentes, em um dos lados da cauda, enquanto, do outro, ocorrem traços oblíquos indistintos, que poderiam repre- sentar a outra parte da nadadeira (Briggs et $a l .$, 1983). Apesar destas evidências, a estrutura precisa da nadadeira caudal permanece indefinida.

Foram encontrados elementos conodontes excepcionalmente grandes (de até $20 \mathrm{~mm}$ ) e aparelhos gigantes de prioniodinídeos da espécie Promissum pulchrum (Theron et al., 1990) na porção basal do Soom Shale Member, do Ordoviciano da África do Sul.

Associados espacialmente a estes elementos, ocorrem traços de partes moles, com feições lobadas e em pares, com tamanhos entre 2,1 mm e 3,1 $\mathrm{mm}$, representados por um filme escuro, situados anteriormente ao aparelho alimentar. Tais estruturas são diretamente comparadas com aquelas do Granton Shrimp Bed, apesar de ambos os aparelhos serem significativamente diferentes (Aldridge \& Theron, 1993).

Em um único espécimen está preservado um traço linear, de cor acinzentada, que se estende atrás do aparelho alimentar. Tal impressão pode representar o tronco do animal, entretanto nenhuma outra feição é observada ou associada a esta estrutura. Com isso, mais espécimens são necessários, para auxiliar na discussão e na comparação entre os diferentes espécimens encontrados.

Partes moles de um animal conodonte do gênero Panderodus foram descobertas no Siluriano de Waukesha, em Wisconsin, nos EUA, porém, somente a porção anterior do corpo foi preservada - a parte posterior não foi encontrada. Tais partes estão impressas na rocha, como uma camada fina de um mineral branco (Smith et al., 1987).

O corpo do animal tem paredes retas e possui um comprimento de $3,4 \mathrm{~mm}$, até o final da porção preservada, porém extrapolações indicam que o comprimento 
máximo seria de $5 \mathrm{~mm}$. 0 animal foi compactado dorso-ventralmente, contrastando com os espécimens do Granton Shrimp, que estão preservados no seu aspecto lateral (Aldridge et al., 1986).

Traços de segmentação são evidentes no animal de Waukesha. No mínimo, sete somitos são delimitados e extrapolações sugerem que seriam mais de vinte somitos na porção preservada. Entretanto, os limites são retos e quase normais, em relação ao eixo sagital, em contraste com a forma em $\mathrm{V}$ desses segmentos nos espécimens do Granton Shrimp (Aldridge et al., 1986).

A assembleia de conodontes está posicionada no final do traço do corpo do animal e ambos dividem o mesmo eixo de simetria. Tanto a assembleia quanto as partes moles do animal são envolvidas por um halo estreito, de cor cinza pálido, que contrasta com a cor avermelhada da rocha (Smith et al., 1987).

A má preservação das partes moles do espécime de Waukesha contribui muito pouco com evidências adicionais na morfologia do animal. Contudo, as dimensões do corpo do animal sugerem que Panderodus não era alongado, como os polygnathaceos de Granton Shrimp, e a simetria preservada da assembleia de Waukesha indica que o espécimen foi achatado no aspecto dorso-ventral, diferindo do aspecto lateral dos espécimes de Granton.

\section{APARELHO ALIMENTAR}

Assim como a afinidade filogenética dos conodontes, o estudo do seu aparelho alimentar tem trazido novas constatações e tem gerado várias discussões entre os paleontólogos (Jeppsson, 1979, 1980; ConwayMorris, 1980; Bengtson, 1980, 1983; Purnell \& von Bitter, 1992; Purnell, 1993) .

A função dos elementos conodontes é proposta em vários modelos (Aldridge, 1987), mas somente dois deles são compatíveis com o tamanho do animal (Briggs et al., 1983; Aldridge et al., 1986) e com o arranjo dos elementos no aparelho alimentar (Aldridge et al., 1987). Um dos modelos estaria relacionado à hipótese de que os conodontes seriam escavadores macrófagos e que seus elementos seriam estruturas utilizadas para agarrar a presa (Jeppsson, 1979). No outro modelo, eles seriam micrófagos filtradores e seus elementos anteriores (elementos ramiformes $\mathrm{S}$ e $\mathrm{M}$ ) teriam funcionado como estruturas ciliadas, que capturavam pequenas partículas de alimento, enquanto os elementos posteriores (elementos pectiniformes P1 e P2) trituravam essas partículas (Nicoll, 1987). Entretanto, tais hipóteses foram refutadas pelo estudo das taxas de crescimento em alguns aparelhos dos ozarkodinídeos (Purnell, 1993, 1994) e pela descoberta de um revestimento, indicativo de desgaste, na superfície de alguns elementos (Purnell, 1995).

Assembleias naturais de conodontes foram encontradas em rochas sedimentares do Carbonífero. Tais assembleias foram examinadas e os especialistas perceberam que elas possuíam um padrão de ocorrência, ou seja, uma organização de elementos no aparelho alimentar, a qual foi denominada padrão standard. Este padrão é produzido, devido ao colapso e ao achatamento da estrutura tridimensional do aparelho, não tendo sofrido modificações entre o decaimento e a fossilização. Modalidades diferentes deste padrão podem ocorrer, devido a variações no corte da rocha, sendo denominados: padrão paralelo, perpendicular e linear (Aldridge et al., 1987).

Importantes achados de assembleias naturais de aparelhos alimentares foram encontrados no Soom Shale Member, do Ordoviciano Superior da África do Sul, com 
ocorrências de aparelhos gigantes, de $6 \mathrm{~mm}$ a $10 \mathrm{~mm}$, denominados Promissum pulchrum (Aldridge \& Theron, 1993), bem como Notiodella keblon, com um aparelho composto por 17 elementos, configurando os pares P1, P2, P3, M, S1, S2, S3, S4 e um elemento S0, que não tem par. Esta é a primeira ocorrência mundial de um aparelho com essa quantidade de elementos, fornecendo, assim, um novo modelo, para uso na reconstrução de aparelhos, a partir das coleções de elementos dispersos, particularmente, para aqueles com elementos P1 do tipo icrion e, talvez, para outros balognatídeos (Aldridge et al., 2013).

Tolmacheva \& Purnell (2002) e, no Canadá, McCracken et al. (1980), Barrick et al. (1976) e Cooper (1974), reconstruíram o aparelho multielemental de conodontes do Siluriano de Oklahoma e de Ohio, da América do Norte.

Para o Devoniano, destacam-se os trabalhos de reconstrução de aparelhos alimentares e de clusters feitos por Klapper \& Philip (1972), por Nicoll (1982, 1984), por Chauffe \& Nichols (1995), por Suttner (2009a, 2009b) e por Suttner et al. (2017).

Estudando assembleias naturais de Idiognathodus do Pensilvaniano, Purnell \& Donoghue (1997) produziram um modelo preciso do aparelho dos ozarkodinídeos, considerado, por eles, um dos mais bem-sucedidos grupos destes vertebrados. Neste modelo, é proposto que os elementos anteriores S e M, dos ozarkodinídeos, seriam fixados a uma placa cartilaginosa. Esses elementos fariam um movimento, no sentido de capturar a presa, e os elementos posteriores seriam responsáveis por rasgar e por triturar o alimento (Purnell \& Donoghue, 1997).

Agematsu et al. $(2008,2017)$ reconstruíram uma associação natural de conodontes do Triássico Inferior do Japão. Outros trabalhos, como os de Orchard (2005) e de
Orchard \& Rieber (1999), reconstruíam aparelhos multielementais de gondolelídeos do Triássico e de neogondolelídeos do Permiano superior e do Triássico Médio.

A descrição dos elementos conodontes está em um estado de fluxo, dado o desejo de descrever biologicamente esses elementos, no que diz respeito à sua posição e à sua orientação, durante a vida do animal conodonte. Esta fase de transição levará algum tempo, tendo em vista que apenas uma pequena porcentagem dos táxons são bem conhecidos, em termos de seus aparelhos, e, também, pelo fato de que os bioestratígrafos costumam considerar apenas o elemento P1, isoladamente. Os termos utilizados na descrição dos elementos conodontes foram resumidos por Sweet (1988) e, posteriormente, discutido por Purnell \& Donoghue (1997).

Assembleias naturais de prioniodinídeos são mal conhecidas ou sequer são conhecidas, dependendo do táxon (Purnell \& Donoghue, 1997; Henderson, 2018). Assim, a ocorrência dos prioniodinídeos do gênero Mesogondolella spp. no Folhelho Lontras é um achado extremamente importante e traz inovações, tanto para o conhecimento dos aparelhos alimentares da Ordem Prioniodinida quanto para o Permiano inferior, no mundo, na América Latina e no Brasil.

\section{A Bacia do Paraná}

\section{1 Contexto estratigráfico}

A Bacia Sedimentar do Paraná abrange, geograficamente, a quase totalidade do centro-sul do Brasil e, também, regiões do norte do Uruguai, do nordeste da Argentina e do leste paraguaio. Trata-se de uma bacia do tipo flexural intracrâtonica, de natureza policíclica, que constitui uma imensa sucessão sedimentar-magmática, com idades entre o Ordoviciano Final (488 Ma) e o 
Cretáceo Final (145 Ma) (Milani et al., 2007).

Diversos ciclos transgressivos/regressivos de um mar, que circundava o supercontinente Gondwana, marcam o registro estratigráfico da Bacia do Paraná, que, segundo Milani et al. (1997), consiste de seis unidades de segunda ordem, denominadas Supersequências: Rio Ivaí (Ordoviciano-Siluriano), Paraná (Devoniano), Gondwana I (Carbonífero-Cretáceo Inicial), Gondwana II (Triássico Médio a Final), Gondwana III (Jurássico Final-Cretáceo Inicial) e Bauru (Cretáceo Final).

A Supersequência Gondwana I apresenta espessura total máxima da ordem de 2.500 m e engloba o maior volume sedimentar da Bacia do Paraná, que reflete uma grande variedade de condições deposicionais. A base dessa supersequência registra um evento glacial do Permocarbonífero, que compreende ambientes terrestre a marinhos, representados pelo Grupo Itararé (Milani et al., 2007), e que atinge uma espessura superior a 1000 metros na porção central da bacia, adelgaçando-se, em direção às bordas norte e sul (França \& Potter, 1988), sendo, neste grupo, que ocorre a unidade portadora de conodontes.

Holz et al. (2010) dividem a Supersequência Gondwana I em sete sequências de $3^{3}$ ordem, denominadas LPTS (Late Paleozoic Third-Order Sequences), em que o Grupo Itararé corresponderia às sequências LPTS 1 (Formação Lagoa Azul) e LPTS 2 (Formação Campo Mourão e Formação Taciba).

Na região de Mafra (SC), Weinschütz \& Castro (2004) reconhecem quatro ciclos de granodecrescência ascendente, culminando com um máximo de inundação da bacia, para o Grupo Itararé, em que, comparando com as unidades propostas por França \& Potter (1988), o primeiro ciclo corresponderia à Fm. Lagoa Azul, o segundo e terceiro ciclos corresponderiam à Fm. Campo Mourão e o quarto ciclo corresponderia à Fm. Taciba.

No afloramento denominado, informalmente, Campo do Centro Paleontológico da Universidade do Contestado (Campaleo) (Figs. 3-4), ocorre a exposição do Folhelho Lontras, unidade que corresponde ao topo da Fm. Campo Mourão e que marca o final do terceiro ciclo/sequência, de Weinschütz \& Castro (2005). Este folhelho marca a fase final de um evento de deglaciação, que inicia com uma camada de, aproximadamente, $7 \mathrm{~m}$ de folhelho microvárvico, rico em clastos caídos na base e que diminuem para o topo, sucedido por uma camada de siltito ricamente bioturbado, com $1 \mathrm{~m}$ de espessura, sotaposto a 1,1 m de folhelho macrofossilífero (fossil largersttaten do Lontras/Campaleo), cuja biota é composta por peixes ósseos e cartilaginosos, escolecodontes, crustáceos, ostracodes, insetos, braquiópodes, poríferos, amonites e fragmentos vegetais, além dos conodontes, que caracterizam um ambiente marinho, restrito e relativamente próximo à linha de costa. Este horizonte fossilífero, em um trabalho de refinamento estratigráfico, foi dividido em quatro níveis, denominados, da base para o topo, 1, 2, 3 e 4, que são limitados por níveis de piritização e que estão subdivididos em intervalos, caracterizados por diferenças sutis no acamamento, na granulometria e nas feições diagenéticas (Fig. 5).

\section{2 Mesogondolella spp. no Folhelho Lontras}

Na América Latina, ainda não foram encontrados restos ou vestígios do animal conodonte. Desde as primeiras pesquisas, quando conodontes foram descobertos, no século XIX, por Pander, até o início do Século XXI, não havia registros de aparelhos alimentares conodontes na América Latina.

Aparelhos alimentares e elementos conodontes prioniodinídeos do gênero $\mathrm{Me}$ - 


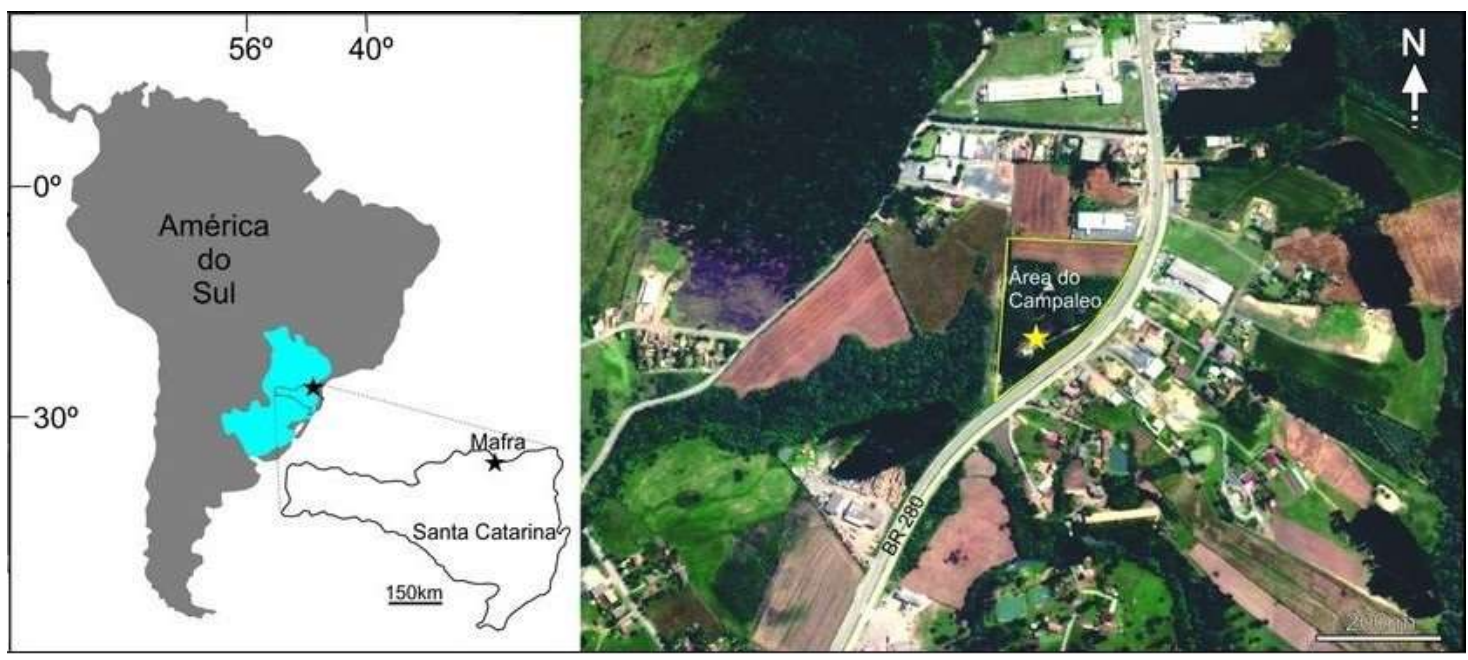

Figura 3 - Localização da única ocorrência de aparelhos alimentares de conodontes na América do Sul. À esquerda, Bacia do Paraná, em azul, e o município de Mafra (SC), marcado pela estrela, em preto. À direita, imagem de satélite extraída do Google Earth, mostrando a área do Afloramento Campaleo, com a estrela, em amarelo, no município de Mafra (composição da figura de Luiz Carlos Weischütz).

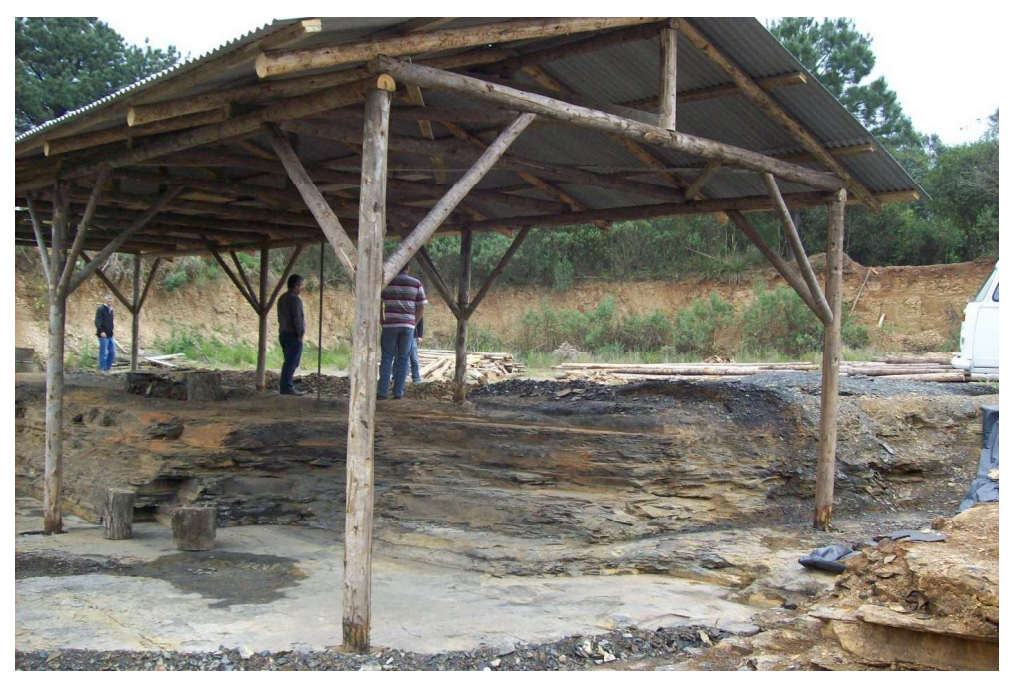

Figura 4 - Fotografia do afloramento Campaleo, no município de Mafra (SC), com detalhe do local de escavação do Folhelho Lontras (acervo de imagens de Everton Wilner).

sogondolella spp. (Kozur, 1988) foram encontrados, pela primeira vez, na América Latina, no Brasil, em Mafra, Santa Catarina, em 2008 (Wilner \& Weinschutz, 2008), e se mantêm como o único registro fossilífero, até hoje. Seguem sendo coletados e estudados, atualmente, em depósitos do Grupo Itararé, Folhelho Lontras, no Afloramento Campaleo, no município de Mafra (SC).

Este importante achado está preservado em alguns níveis do folhelho fossilífero
(Fig. 5), predominantemente, como assembleias naturais (aproximadamente, 150 achados) e como possíveis clusters (em torno de 200 exemplares), de cores âmbar, branco e hialino (Fig. 6), constituindo as primeiras ocorrências de aparelhos alimentares em bacias sedimentares da América Latina (Wilner et al., 2016).

Os aparelhos alimentares possuem, aproximadamente, $5 \mathrm{~mm}$ de tamanho e ocorrem no plano do acamadamento do fo- 


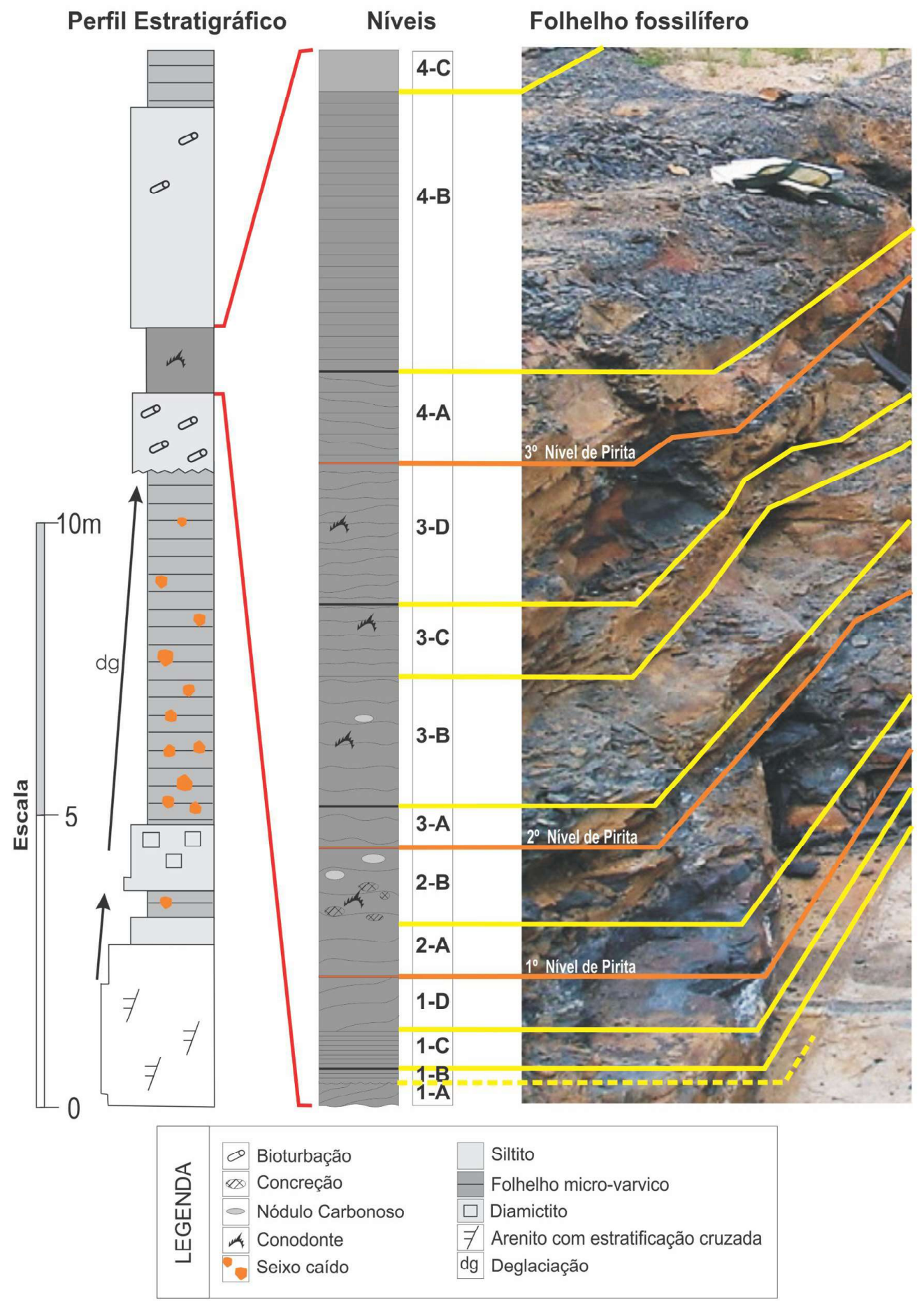

Figura 5 - Perfil estratigráfico do Afloramento Campaleo, com detalhe do Folhelho Lontras, evidenciando os níveis de pirita e a ocorrência dos conodontes nos níveis 2B, 3B, 3C e 3D (composição da figura por Luiz Carlos Weischütz). 

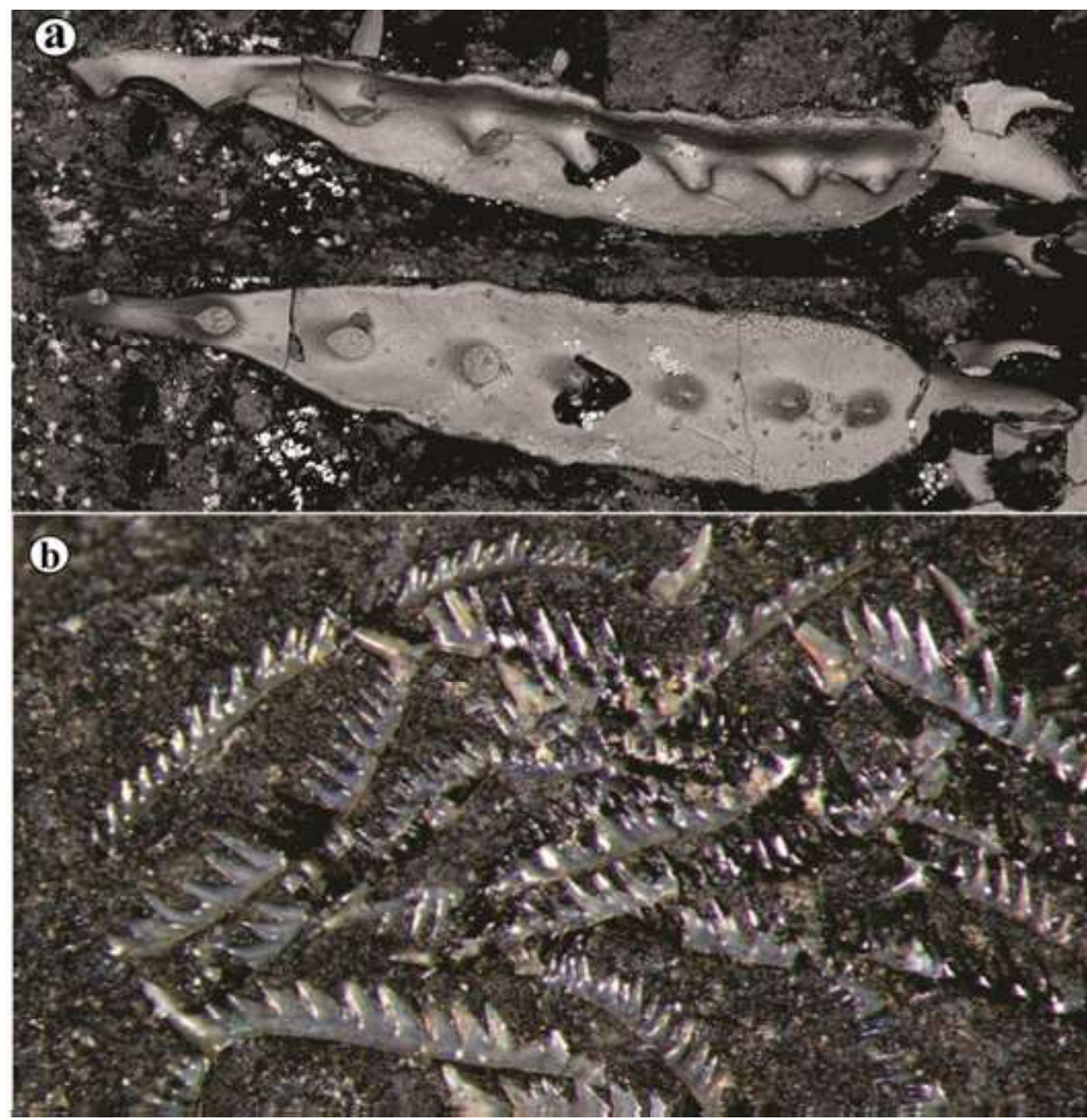

Figura 6 - Detalhe do aparelho alimentar de Mesogondolella spp.: A) Microscopia Eletrônica de Varredura do elemento P, com aumento de 130X (imagem obtida por Mark Purnell); e B) Estereomicroscopia dos elementos ramiformes, com aumento de 80X (imagem obtida por Everton Wilner).

lhelho fossilífero. São observados conjuntos mais completos, com 15 elementos, e outros, incompletos. Em alguns exemplares, estão preservados os elementos pectiniformes $\mathrm{P} 1$ e os elementos ramiformes $\mathrm{S}$ e M. Em outros exemplares, ocorrem apenas os elementos ramiformes, evidenciando que, provavelmente, haja mais de um táxon nessa localidade.

As feições diagnósticas, para determinação taxonômica, observadas na morfologia dos elementos pectiniformes P1 auxiliaram na identificação do gênero Mesogondolella, atribuída à Mesogondolella spp., superfamília Gondolelloidea, relacionada às biozonas Mesogondolella belladontae e $M$. bisselli, do Cisuraliano, respectivamente, Asseliano - Artinskiano, para províncias temperadas, correlata à biozona Sweetognathus whitei para províncias equatoriais (Henderson, 2018). Esta atribuição bioestratigráfica corrobora com a idade isocrônica $\mathrm{Rb} / \mathrm{Sr}$ em rocha total de $287 \pm 10$ Ma (Koester et al., 2016), advinda do mesmo nível de ocorrência dos espécimens de Mesogondolella do Afloramento Campaleo.

\section{CONSIDERAÇõES FINAIS}

Conodontes são vertebrados primitivos extintos, predadores, livre natantes e exclusivamente marinhos, encontrados do Cambriano ao Triássico.

\section{Edição da Sociedade Brasileira de Geologia - Núcleo RS/SC}


A única parte mineralizada são os elementos conodontes, compostos por fosfato de cálcio. Partes orgânicas foram encontradas no Carbonífero da Escócia e acenderam o debate, com relação à afinidade filogenética desses animais, que são, hoje, considerados vertebrados primitivos. A função dos elementos conodontes, como peças mastigatórias, e a evidência de macrofagia nesses vertebrados primitivos, analisada através dos diversos aparelhos alimentares, preservados na forma de assembleias naturais e de clusters, suportam a hipótese de que os primeiros vertebrados eram predadores marinhos.

Eles são utilizados para estabelecer a maturação da matéria orgânica, através do seu Índice de Alteração de Cor (IAC), mas sua maior importância se deve ao fato de que os conodontes têm uma ampla ocorrência mundial e têm uma ótima variação morfológica no tempo, tornando-os excelentes ferramentas no zoneamento bioestratigráfico do Paleozoico, além de serem importantes indicadores das condições paleoecológicas do meio em que viviam e de constituírem peça fundamental na discussão sobre a idade dos primeiros vertebrados.

Suas ocorrências fossilíferas decorrem de raros achados do animal conodonte, de poucos aparelhos alimentares e de diversificados e abundantes elementos conodontes em diversos depósitos marinhos de províncias de águas quentes a frias, em bacias sedimentares paleozoicas e triássicas mundiais. Tiveram seu apogeu entre o Ordoviciano e o Devoniano, com ocorrências reduzidas, a partir do Carbonífero, desaparecendo completamente no Triássico.

No Brasil, são encontrados, como elementos conodontes, nas bacias do norte, e, como aparelhos alimentares, excepcionalmente bem preservados, nos folhelhos fossilíferos do Folhelho Lontras, historicamente considerado como Permocarbonífero. Com os achados de Mesogondolella spp., relacionados às biozonas Mesogondolella belladontae e M. bisselli, esses depósitos marinhos deglaciais têm seu posicionamento estratigráfico no Cisuraliano.

\section{REFERÊNCIAS}

Agematsu, S., Orchard, M. J. \& Sashida, K. 2008. Reconstruction of an Apparatus of $\mathrm{Ne}$ ostrachanognathus Tahoensis from Oitate, Japan and species of Neostrachanognathus from Oman. Palaeontology, 51(5): 12011211.

Agematsu, S., Uesugi, K., Sano, H. \& Sashida, K. 2017. Reconstruction of the multielement apparatus of the earliest Triassic conodont, Hindeodus parvus, using synchrotron radiation X-ray micro-tomography. Journal of Paleontology, 9: 1120-1127.

Aldridge, R. J. \& Briggs, D. E. G. 1989. A soft body of evidence. Natural History, 5(89): 611.

Aldridge, R. J., Briggs, D. E. G., Clarkson, E. N. K. \& Smith, M. P. 1986. The affinities of conodonts - new evidence from the Carboniferous of Edinburgh, Scotland. Lethaia, 19: 279291.

Aldridge, R. J., Briggs, D. E. G., Smith, M. P., Clarkson, E. N. K. \& Clark, N. D. L. 1993. The anatomy of conodonts. Philosophical Transaction of Royal Society of London, 340(B): 405-421.

Aldridge, R. J., Duncan J. E., Murdock, D. J. E., Sarah, E., Gabbott, S. E. \& Theron, J. N. 2013. A 17-element Conodont Apparatus from the Soom Shale Lagerstatte (Upper Ordovician). South Africa Palaeontology, 56(2): 261-276.

Aldridge, R. J. \& Purnell, M. A. 1996. The conodont controversies. Tree - Elsevier trends Journals, 11(11): 463-468.

Aldridge, R. J., Smith, M. P., Norby, R. D. \& 
Briggs, D. E. G. 1987. The architecture and function of Carboniferous polygnathacean conodont apparatuses. In: Aldridge, R. J. (Ed. ). Palaeobiology of conodonts. Chichester, Ellis Horwood, p. 63-75.

Aldridge, R. J. \& Theron, J. N. 1993. Conodonts with preserved soft tissue from a new Ordovician Konservat-Lagerstätte. Journal of Micropalaeontology, 12(1): 113-117.

Barrick, J. E. \& Klapper, G. 1976. Multielement Silurian (late Llandoverian - Wenlockian) conodonts of the Clarita Formation, Arbuckle Mountains, Oklahoma, and phylogeny of Kockelella. Geologica et Palaeontologica, 10: 59-100.

Bengtson, S. 1980. Conodonts: the need for a functional model. Lethaia, 13: 320.

Bengtson, S. 1983. A functional model for conodonts apparatus. Lethaia, 16: 38.

Blieck, A. 1992. At the Origin of Chordates. Geobios, 25: 101-113.

Briggs, D. E. G. 1992. Conodonts: A major extinct group added to the vertebrates. Science, 256: 1285-1286.

Briggs, D. E. G., Aldridge, R. J. \& Smith, M. P. 1987. Conodonts are not aplacophoran molluscs. Lethaia, 20: 381-382.

Briggs, D. E. G., Clarkson, E. N. K. \& Aldridge, R. J. 1983. The conodont animal. Lethaia, 16: 1-14.

Chauffe, K. M. \& Nichols, P. A. 1995. Multielement conodont species from the Louisiana Limestone (Upper Devonian) of west-central Illinois and north-eastern Missouri, U. S. A. Micropaleontology, 41: 171-186.

Conway-Morris, S. 1980. Conodont function: fallacies of the tooth model. Lethaia, 13: 107108.

Conway-Morris, S. 1989. Conodont palaeobiology: recent progress and unsolved problems. Terra Nova, 1: 135-150.
Cooper, B. J. 1974. Studies of multielement Silurian conodonts. Columbus. Ohio State University. (inédito)

Cooper, B. J. 1975. Multielement conodonts from the Brassfield Limestone (Silurian) of Southern Ohio. Journal of Paleontology, 49: 984-1008.

Davydov, V. I., Korn, D. \& Schmitz, M. D. 2012. The Carboniferous Period. In: Gradstein, F. M., Ogg, J. G., Schmitz, M. \& Ogg, G. (Eds. ). The Geologic Time Scale 2012. Elsevier, Amsterdam, p. 603-651.

Donoghue, P. C. J., Forey, P. L. \& Aldridge, R. J. 2000. Conodont affinity and chordate phylogeny. Biological Review, 75: 191-251.

Donoghue, P. C. J., Purnell, M. A. \& Aldridge, R. J. 1998. Conodont anatomy, chordate phylogeny and vertebrate classification. Lethaia, 31: 211-219.

Dzik, J. 1986. Chordate Affinities of the Conodonts. In: Hoffman, A. \& Nitecki, M. H. (Eds. ). Problematic Fossil Taxa. Oxford Monographs on Geology and Geophysics, New York Oxford University Press, 5, p. 240-254.

Epstein, A. G., Epstein, J. G. \& Harris, L. D. 1977. Conodont color alteration - an index to organic metamorphism. U. S. Geological Survey Professional Paper, 995: 27.

França, A. B. \& Potter, P. E. 1988. Estratigrafia, ambiente deposicional e análise de reservatório do Grupo Itararé (Permocarbonífero), Bacia do Paraná (Parte 1). Boletim de Geociências da PETROBRÁS, 2(2-4): 147-191.

Forey, P. \& Janvier, P. 1993. Agnathans and the origin of jawed vertebrates. Nature, 361 : 129-134.

Henderson, C. M. 2018. The Permian Timescale. In: Lucas, S. G. \& Shen, S. Z. (Eds. ). Geological Society, London, Special Publications, 450, p. 119-142.

Holz, M., França, A. B., Souza, P. A. \& Iannuz- 
zi, R. 2010. Stratigraphic chart of the Late Carboniferous/Permian succession of the eastern border of the Paraná Basin, Brazil, South America. Journal of South American Earth Sciences, 29(2): 381-399.

Janvier, P. 1988. Conodont affinity: a reply. Lethaia, 21: 27.

Janvier, P. 1995. Conodonts join the club. Nature, 374: 761-762.

Janvier, P. 1996. Evolution, palaeobiogeography, and life history. In: Early Vertebrates, Oxford Monographs on Geology and Geophysics, 33, p. 281-284.

Jeppson, L. 1979. Conodont element function. Lethaia, 12: 153-171.

Jeppson, L. 1980. Function of the conodont elements. Lethaia, 13: 228.

Klapper, G. \& Philip, G. M. 1972. Familial classification of reconstructed Devonian conodont apparatuses. Geologica et Palaeontologica, SB1: 97-105.

Koester, E., Scomazzon, A. K., Weinschütz, L. C., Wilner, E., Moutinho, L. P. \& Nascimento, S. 2016. Idade Rb-Sr do Folhelho Lontras, Grupo Itararé, Bacia do Paraná, Na Região de Mafra, SC, Brasil. In: CONGRESSO BRASILEIRO DE GEOLOGIA, 48., 2016, Porto Alegre. Anais... Porto Alegre, SBG, v. 1, p. 955.

Kozur, H. 1988. Division of the gondolellid platform conodonts. In: Ziegler, W. (ed. ). FIRST INTERNATIONAL SENCKENBERG CONFERENCE AND FIFTH EUROPEAN CONODONT SYMPOSIUM (ECOS V). Contr. 1, part 2: Abstracts of meeting. Courier Forschungsinstitut Senckenberg, 102: 244-245.

Lemos, V. B. 1992a. Conodontes do Carbonífero das Bacias do Amazonas e Solimões. Taxonomia - Parte I: Pesquisas, 19: 75-93.

Lemos, V. B. 1992b. Conodontes do Carbonífero das Bacias do Amazonas e Solimões. Taxonomia - Parte II: Pesquisas, 19: 120-131.
Lemos, V. B. \& Scomazzon, A. K. 2001. The Carboniferous biochronostratigraphy of the Amazonas Basin, Brazil based on conodonts. In: Melo, J. H. G. \& Terra, G. S. T. (Eds. ). Ciência Técnica Petróleo. p. 131-138. (seção Exploração de Petróleo, n. 20)

Lemos, V. B. \& Silva, O. B. 1996. Ciclos Sedimentares e Ocorrência de Conodontes e Fusulinídeos na Bacia do Acre- Plataforma Carbonática da Fm. Cruzeiro-Eirunepê, Permiano Inferior. In: Simpósio de Geologia da Amazônia, 5., Belém, 1996. Anais. . . Belém, SBG, p. 188-191.

McCracken, A. D., Nowlan, G. S. \& Barnes, C. R. 1980. Gamachignathus, a New Multielement Conodont Genus from the latest Ordovician, Anticosti Island, Quebec. Geological Survey of Canada Paper, 80(1C): 103-112.

Milani, E. J. 1997. Evolução tectono-estratigráfica da Bacia do Paraná e seu relacionamento com a geodinâmica fanerozóica do Gondwana sul-ocidental. Porto Alegre. Tese de Doutorado, Programa de Pós-graduação em Geociências, Instituto de Geociências, Universidade Federal do Rio Grande do Sul.

Milani, E. J., Rangel, H. D., Bueno, G. V., Stica, J. M., Winter, W. R., Caixeta, J. M. \& Pessoa Neto, 0. C. 2007. Bacias sedimentares brasileiras: cartas estratigráficas. Anexo ao Boletim de Geociências da Petrobrás, 15(1): 183-205.

Müller, K. J. 1981. Zoological Affinities of Conodonts. In: Robison, R. A. (Ed.) Treatise on Invertebrate Paleontology, Part W, Suppl. 2, Conodonta. Lawrence, Geological Society of America, University Press, p. W79-W82.

Nascimento, S., Scomazzon, A. K., Lemos, V. B., Moutinho, L. P. \& Matsuda, N. S. 2010. Bioestratigrafia e Paleoecologia com base em conodontes em uma seção de carbonatos marinhos do Pensilvaniano inferior, Formação Itaituba, borda sul da Bacia do Amazonas, Brasil. Pesquisas em Geociências, 3: 243-256.

Nicoll, R. S. 1982. Multielement composition of the conodont Icriodus expansus Branson \& 
Mehl, from the Upper Devonian of the Canning Basin, Western Australia. Journal of Australian Geology and Geophysics, 7: 197-213.

Nicoll, R. S. 1984. Multielement composition of the conodont species Polygnathus xylus xylus Stauffer, 1940 and Ozarkodina brevis (Bischoff \& Ziegler, 1957) from the Upper Devonian of the Canning Basin, Western Australia. BMR Journal of Australian Geology and Geophysics, 9(2): 133-147.

Nicoll, R. S. 1987. Form and Function of Pa elements in the conodont animal. In: Aldridge, R. J. (Ed. ). Palaeobiology of conodonts. Chichester: Ellis Horwood, p. 77-90.

Orchard, M. J. 2005. Multielement conodont apparatuses of Triassic Gondolleloidea. In: Purnell, M. A. \& Donoghue, P. C. J. (Eds). Conodont biology and phylogeny: interpreting the fossil record. Special Papers in Palaeontology, 73: 73-101.

Orchard, M. J. \& Rieber, H. 1999. Multielement Neogondolella (e). In: Serpagli, E. (Ed. ). Studies on conodonts. Proceedings of the Seventh European Conodont Symposium, Bologna-Modena, Italy, June 1998. Bollettino della Società Palaeontologica Italiana, 37: 475-488.

Pander, C. H. 1856. Monographie der fossilen Fische des silurische Systems der russisch-baltischen Gouvernements. Saint Petersburg, 91p.

Pridmore, P. A., Barwick, R. E. \& Nicoll, R. S. 1997. Soft anatomy and affinities of conodonts. Lethaia, 29: 317-328.

Purnell, M. A. 1993. Feeding mechanisms in conodonts and the function of the earliest vertebrate hard tissues. Geology, 21: 375377.

Purnell, M. A. 1994. Skeletal ontogeny and feeding mechanisms in conodonts. Lethaia, 27: 129-138.

Purnell, M. A. 1995a. Large eyes and vision in conodonts. Lethaia, 28: 187-188.
Purnell, M. A. 1995b. Microwear on conodont elements and macrophagy in the first vertebrates. Nature, 374: 798-800.

Purnell, M. A., Aldridge, R. J., Donoghue, P. C. J. \& Gabbott, S. E. 1995. Conodonts and the First Vertebrates. Elsevier Science, 19(1): 2027.

Purnell, M. A. \& Donoghue, P. C. J. 1997. Architecture and functional morphology of the skeletal apparatus of ozarkodinid conodonts. Philosophical Transaction of Royal Society of London, 352(B): 1545-1564.

Purnell, M. A. \& von Bitter, P. H. 1992. Bladeshaped conodont elements functioned as cutting teeth. Nature, 359: 629-630.

Sansom, I. J., Smith, M. P. \& Armstrong, H. A. 1992. Presence of the earliest vertebrate hard tissues in conodonts. Science, 256: 1308-1311.

Sansom, I. J., Smith, M. P. \& Smith, M. M. 1994. Dentine in conodonts. Nature, 368: 591.

Scomazzon, A. K., Moutinho, L. P., Nascimento, S., Lemos, V. B. \& Matsuda, N. S. 2016. Conodont biostratigraphy and paleoecology of the marine sequence of the Tapajós Group, Early-Middle Pennsylvanian of Amazonas Basin, Brazil. Journal of South American Earth Sciences, 65: 25-42.

Scomazzon, A. K., Wilner, E., Purnell, M. A., Nascimento, S., Weinschütz, L. C., Lemos, V. B., Souza, F. L. \& Silva, C. P. 2013. First report of conodont apparatuses from Brazil - Permian of Paraná Basin, Itararé Group, Lontras Shale - Evidence of Gondwana deglaciation. Conodont from the Andes. In: INTERNATIONAL CONODONT SYMPOSIUM, 3., 2013, Mendoza. Paleontological Note, Publicación Especial no 13, p. 99-102.

Smith, M. P, Briggs, D. E. G. \& Aldridge, R. J. 1987. A conodont animal from the lower Silurian of Wisconsin, USA, and the apparatus architecture of panderodontid conodonts. In: Aldridge, R. J. (Ed. ). Palaeobiology of co- 
nodonts. Chichester, Ellis Horwood, p. 91104.

Suttner, T. J. 2009a. An ozarkodinid conodont cluster from Kirchfidisch (Lower Devonian, Austria). Annalen des Naturhistorischen $\mathrm{Mu}$ seums in Wien, 111A: 233-244.

Suttner, T. J. 2009b. Lower Devonian conodont clusters from southern Burgenland (Austria). Berichte der Geologischen Bundesanstalt, 79: 40-41.

Suttner, T. J., Kido, E. \& Briguglio, A. 2017. A New Icriodontid Conodont Cluster with Specific Mesowear Supports an Alternative Apparatus Mtion Model for Icriodontidae. Journal of Systematic Palaeontology, 16(11): 909-926. Disponível em: https://www. tandfonline. com/loi/tjsp20. Acesso em: 03 jun. 2020.

Sweet, W. C. 1988. The Conodonta, Morphology, Taxonomy, Palaeoecology and Evolutionary History of a Long-Extinct Animal Phylum. Oxford Monographs on Geology and Geophysics, 10, 212p.

Szaniawski, H. 1987. Preliminary structural comparisons of protoconodont, paraconodont, and euconodont elements. In: Aldridge, R. J. (Ed. ). Palaeobiology of conodonts. Chichester, Ellis Horwood, p. 35-47.

Theron, J. N., Rickards, R. B. \& Aldridge, R. J. 1990. Bedding plane assemblages of Promissum pulchrum, a new giant Ashgill conodont from the Table Mountain Group, South Africa. Palaeontology, 33: 577-594.

Tolmacheva, T. Y., Purnell, M. A. 2002. Apparatus composition, growth, and survivorship of the Lower Ordovician conodont Paracordylodus gracilis Lindström, 1955. Palaeontology, 45: 209-228.

Weinschütz, L. C. \& Castro, J. C. 2004. Arcabouço cronoestratigráfico da Formação Mafra (intervalo médio) na região de Rio Negro/ PR-Mafra/SC, borda leste da Bacia do Paraná. Rem: Revista Escola de Minas, 57(3): 151156.
Weinschütz, L. C. \& Castro, J. C. 2005. A sequência Mafra superior $\backslash$ Rio Do Sul inferior (Grupo Itararé, permocarbonífero) em sondagens testemunhadas da região de Mafra (SC), Margem Leste da Bacia do Paraná. Geociências, São Paulo, 24(2): 131-141.

Wilner, E., Lemos, V. B. \& Scomazzon, A. K. 2016. Associações naturais de conodontes Mesogondolella spp, Grupo Itararé, Cisuraliano da Bacia do Paraná. GAEA Journal of Geos ciences, 9(1): 30-36.

Wilner, E. \& Weinschütz, L. C. 2008. Ocorrência de Conodontes da Formação Rio do Sul, Grupo Itararé, Permocarbonífero da Bacia Sedimentar do Paraná na região de Mafra. In: PALEO 2008 PR/SC, Ponta Grossa, 2008. Boletim Info. da Soc. Bras. Paleontologia. Ponta Grossa. 